\title{
Measuring the Affordability of Residential Building Innovations
}

Chi J. Leng

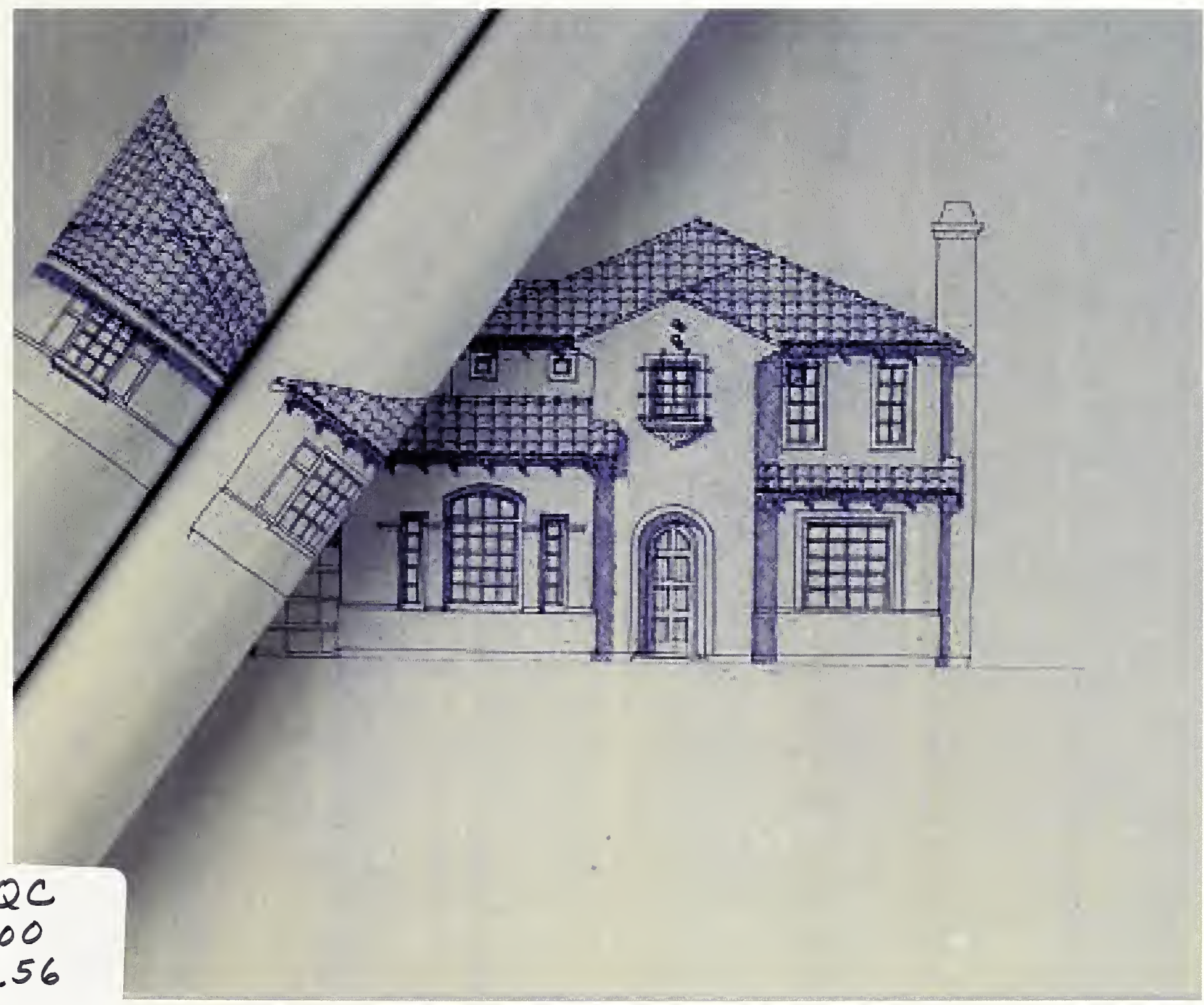

\#233

2005 

U.S. Department of Commerce

Technology Administration

National Institute of Standards and Technology
Office of Applied Economics

Building and Fire Research Laboratory

Gaithersburg, MD 20899

\section{Measuring the Affordability of Residential Building Innovations}

Chi J. Leng

Sponsored by:

U.S. Department of Housing and Urban Development

Office of Policy Research and Development

Washington, DC 20410

June 2005

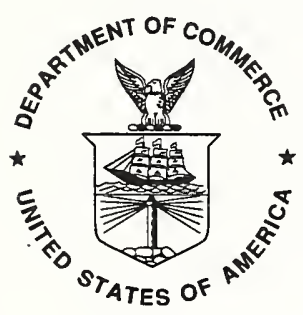

U.S. DEPARTMENT OF COMMERCE

Carlos M. Gutierrez, Secretary

TECHNOLOGY ADMINISTRATION

Michelle O'Neill, Deputy Under Secretary for Technology

NATIONAL INSTITUTE OF STANDARDS AND TECHNOLOGY

Hratch Semerjian, Director (Acting) 


\section{Abstract}

Innovations in residential construction have faced many barriers to adoption. One critical barrier is the absence of metrics that allow homeowners, home builders, and homebuyers to compare the cost effectiveness, or affordability, of adopting these new technologies in owner-occupied housing. To address this barrier, the Department of Housing and Urban Development (HUD) and the National Institute of Standards and Technology (NIST) are working together to develop such metrics and to outline steps to promote their use. This report builds on a series of workshops, papers, and publications that have been held and produced over a two-year period to define affordability metrics and describe a roadmap for their dissemination.

This report identifies key stakeholders in the adoption of residential construction innovations, explores innovation in the construction industry, and describes barriers to the adoption of these innovations. The report culminates in a discussion of technical metrics for affordability and how to develop and guide the process for dissemination and implementation of these metrics. Proposed technical metrics evaluate the affordability of new residential building technologies. These metrics allow homeowners and other decision makers to compute the costs of purchasing, installing, and operating new technologies and to compare these costs with those of existing technologies. The metrics will also allow users to take into account the salvage value of the new technology when the home is sold. They address uncertainties associated with use of new technologies, such as those relating to performance, durability, and maintenance and operations costs. The metrics build on established building economics methodologies, such as life-cycle costing as described in ASTM Standard Practice E 917 (ASTM International, 2002b). This report concludes with a roadmap for policymakers and other interested parties to promote the use of technical metrics and to evaluate the affordability of new residential housing technologies.

Keywords: affordability, building economics, diffusion of innovations, life-cycle cost, residential construction 


\section{Acknowledgments}

The Office of Applied Economics would like to thank all those who contributed numerous excellent ideas to this report. The author in particular would like to express her appreciation to Mr. David Engel, Dr. Carlos E. Martín, and Mr. Dana B. Bres of the Office of Policy Development and Research (PD\&R) at the U.S. Department of Housing and Urban Development (HUD) for their guidance, suggestions, and support. Also appreciated is Dr. Christopher C. White of the Materials and Construction Research Division of the Building and Fire Research Laboratory (BFRL) of the National Institute of Standards and Technology (NIST) for his efforts to coordinate HUD-related research within BFRL and for his comments and suggestions in support of this publication. Special thanks are extended to Dr. Harold E. Marshall, Dr. Robert E. Chapman, Dr. Sieglinde K. Fuller, and Dr. M. Hayden Brown of BFRL's Office of Applied Economics for their thorough reviews, careful suggestions, and continuous support. The author would like to thank Mr. William I. Whiddon and Mr. David B. Hattis of Building Technology Incorporated for their creative contributions. Finally, special appreciation is extended to the participants of the Roadmap to Technical Metrics for Housing Affordability Workshop who contributed lively discussion and thoughtful comments that have been incorporated into the report: Mr. William Asdal, Asdal Builders; Ms. Linda Braley, Appraisal Institute; Mr. Paul Emrath, National Association of Home Builders; Ms. Dottie Harris, New York Department of State; Dr. C. Theodore (Ted) Koebel, Virginia Center for Housing Research, Virginia Polytechnic Institute and State University; and Dr. T. Michael Toole, Bucknell University. 


\section{Table of Contents}

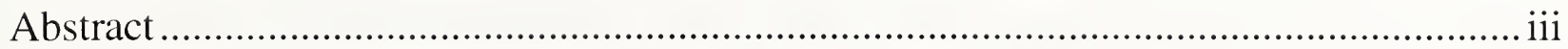

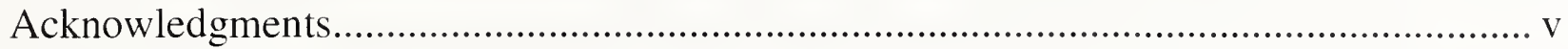

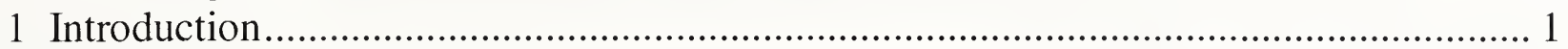

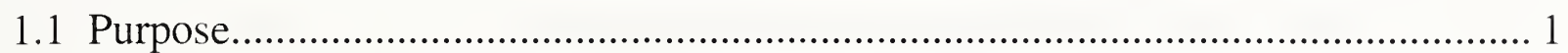

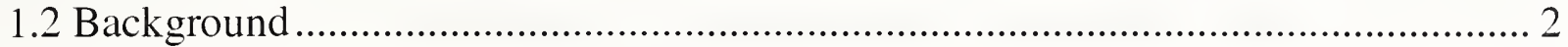

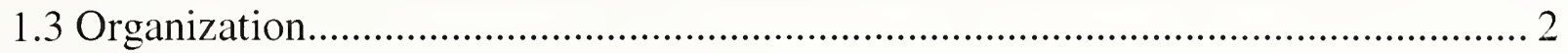

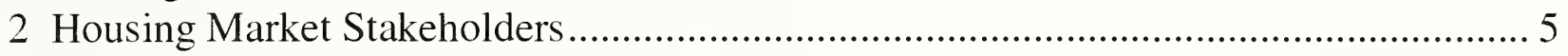

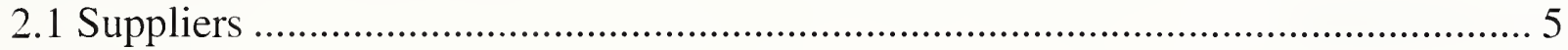

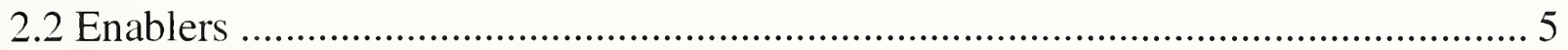

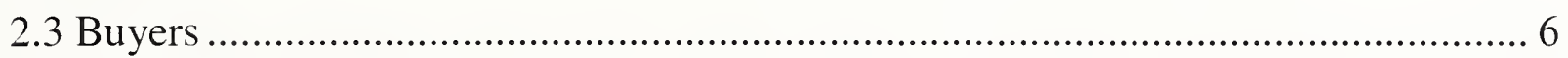

2.4 Regulatory Environment ................................................................................. ?

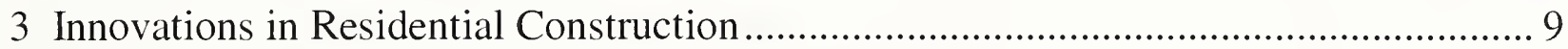

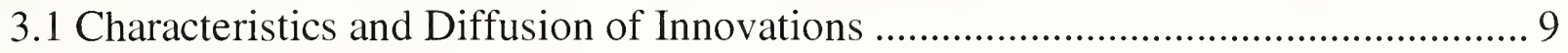

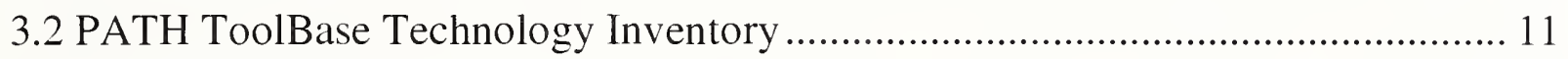

3.3 Barriers to Adoption of Housing Innovations........................................................... 13

4 Measuring the Affordability of Residential Building Innovations: A Methodology.... 17

4.1 Proposed Affordability Metrics ............................................................................... 17

4.2 Proposed Metrics for Measuring Affordability, by Stakeholder ............................. 20

4.3 Proposed Metrics for Measuring Affordability by New Construction vs. Existing

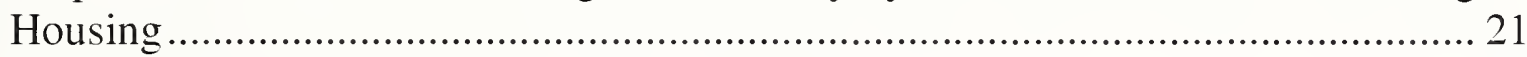

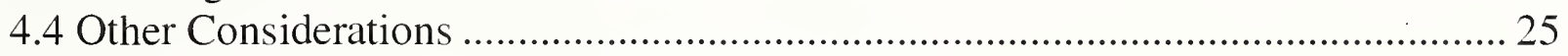

5 Roadmap for Dissemination of Affordability Metrics................................................. 27

5.1 Reduce Uncertainty and Information Gap Facing Consumers ................................ 28

5.2 Drive Acceptance by Homebuilders and Remodelers .............................................. 29

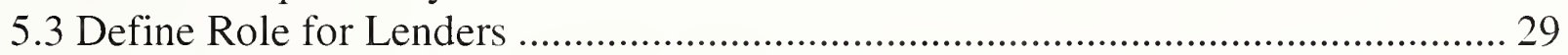

5.4 Provide Guidance to Local Code Officials .......................................................... 30

6 Summary and Recommendations for Further Research ............................................ 31

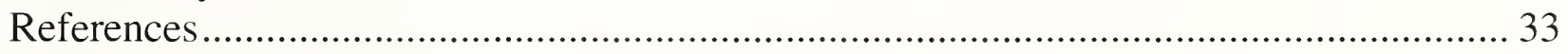

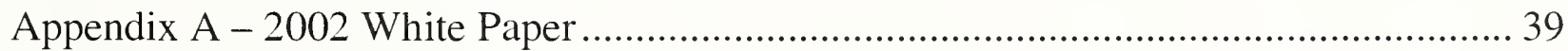

Appendix B - History, Trends, and Data......................................................................... 43

B.1 Current and Historical Rates of Homeownership .................................................... 43

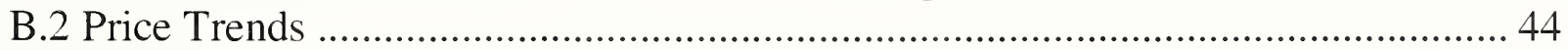

B.3 Housing Supply: Existing Stock and New Construction Flows.............................. 46

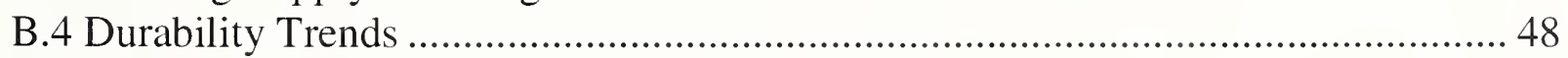

Appendix C - PATH ToolBase: Technology Inventory................................................... 49 


\section{List of Tables}

Table 3-1 Potential for Adopting an Innovation Classified by Building Classification and by Type of Construction-Related Activity............................................ 11

Table 3-2 Barriers by Stakeholder ...............................................................14

Table 4-1 Summary of Cost Components for Residential Construction Innovations .23, 31

Table 5-1 Summary of Methods of Dissemination, by Stakeholder. $.27,32$

\section{List of Figures}

Figure 4-1 Affordability Metrics for New Construction and Existing Housing ...............21 Figure 4-2 Sample Cash Flow Diagram for Homeowners, Case C: New Construction....25 Figure 4-3 Sample Cash Flow Diagram for Homeowners, Case D: Existing Construction (12 year-old home) 
"When you can measure what you are speaking about, and express

it in numbers, you know something about it; but when you cannot

measure it, when you cannot express it in numbers, your

knowledge is of a meagre and unsatisfactory kind."

$\sim$ William Thomson, Lord Kelvin, May 3, 1883

\section{Introduction.}

\subsection{Purpose}

A clause on affordability of housing has been added to the International Residential Code (International Conference of Building Officials, 2000). Its inclusion was motivated by a desire among stakeholders to take into consideration the impact of regulations on firstcost affordability of homes. There is, however, no standard, uniform, or accepted definition of affordability that code officials can use to define and measure affordability. Without a set of metrics to measure affordability, manufacturers, code officials, builders, and consumers will not be able to evaluate the affordability of new housing technologies in owner-occupied housing. To address this barrier, the Department of Housing and Urban Development (HUD) and the National Institute of Standards and Technology (NIST), in collaboration with key housing industry stakeholders, are working together to develop such metrics and to outline steps to promote their use.

Two long-standing objectives of the U.S. Department of Housing and Urban Development (HUD) have been to increase homeownership opportunities and promote decent affordable housing (U.S. Department of Housing and Urban Development, 2003). Residential building innovations provide options that enable homeowners to reduce these monthly housing expenses. But innovations in residential construction have faced many barriers to adoption in owner-occupied housing. One critical barrier is the absence of affordability metrics that allow homeowners, home builders, homebuyers, and other decisions makers to compare the cost effectiveness of adopting these new technologies against incumbent technologies.

The purpose of this report is to develop affordability metrics for housing innovations for owner-occupied housing and propose a roadmap to disseminate those metrics. Affordability is defined as the condition of "having the financial means for or bearing the cost of" (American Heritage (B) Dictionary of the English Language, 2000). In the housing industry, affordability of owner-occupied housing and of residential building innovations consists of two components: cost and ability to pay. This report, however, addresses cost exclusively. ${ }^{1}$ It describes how to measure and evaluate the affordability of

\footnotetext{
${ }^{1}$ The ability of a potential homebuyer to pay for housing is driven by income. employment history, education, and labor market conditions. Because in most cases ability to borrow affects ability to pay. credit history and debt burden, which are key determinants of ability to borrow, are also factors affecting affordability. Although ability to pay is a key aspect of affordability, it is beyond the scope of this study, which focuses on the development of cost metrics for owner-occupied housing.
} 
alternative residential building technologies when compared with a conventionally used technology satisfying the same function or code requirement. It accommodates the lifecycle cost measurement methodology, as outlined in ASTM standard practice E 917 (ASTM International, 2002b). Dissemination of affordability metrics will result in a more rapid introduction of new, more affordable technologies in housing, thereby supporting HUD's first two Programmatic Strategic Goals: to increase homeownership opportunities, and to promote decent affordable housing in American communities (U.S. Department of Housing and Urban Development, 2003).

\subsection{Background}

This report builds on innovation research and a series of workshops, papers, and publications that have been produced over a two-year period. HUD sponsored a two-day workshop, "Measuring and Assessing the Consequences of Technology and Innovation for Affordability of Housing," held at NIST in June 2003. The workshop developed ideas introduced in a 2002 white paper by Chapman and Marshall, which is included as Appendix A in this report, through the participation and contributions of members of key stakeholder groups in the residential construction industry. The proceedings from the June 2003 workshop were summarized in a report by Whiddon, Hattis, and Leng (2004) and published by NIST. A subsequent workshop, "Roadmap to Technical Metrics for Housing Affordability," was held at NIST in July 2004, to address more specific affordability measurement issues. This report draws from the discussions, knowledge, ideas, and suggestions shared by participants of both workshops to develop affordability metrics for new housing technologies.

\subsection{Organization}

This report presents the history and background, metrics, and road-mapping activity of the project that NIST is leading for HUD. Chapter 2 describes housing market stakeholders that are key to the adoption of residential building innovations, and Chapter 3 examines the types and diffusion of innovation in the residential construction industry, discusses other barriers to the adoption of innovations, and describes the Partnership for Advancing Technology in Housing (PATH) ToolBase's list of housing innovations.

Chapter 4 presents technical metrics for affordability and how to develop and guide the process for dissemination and implementation of these metrics. The proposed technical metrics evaluate the affordability of new residential building technologies. These metrics build on the established life-cycle cost building economics methodology, as described in ASTM Standard Practice E 917 (ASTM, 2002b). They address uncertainties associated with use of new technologies, such as those relating to performance, durability, maintenance and operations costs, and valuation. Chapter 5 proposes a roadmap for policymakers and other interested parties to disseminate and promote the use of technical metrics to evaluate the affordability of new technologies. The report concludes with a summary and suggestions for future research in Chapter 6. 
Appendix A contains the white paper that describes the motivation for and conception of this research effort. Appendix B describes the historical background which provides the context for adoption of innovations in the residential construction industry: a statistical snapshot of homeownership in the United States, an outline of price trends in residential sales, and a description of the existing stock of housing and the inflows of new construction. Appendix $\mathrm{C}$ lists the technologies included in the PATH ToolBase technology inventory. These technologies in this inventory, which is described in section 3.2 of this report, are examples of technologies whose adoption improves affordability for homeowners. 


\section{Housing Market Stakeholders}

The introduction and diffusion of innovations into residential construction - whether through new materials or new construction processes - is greatly influenced by stakeholders in the housing market. The stakeholders and actors in U.S. housing markets are loosely grouped into four categories: suppliers, enablers, buyers, and regulators. These groups interact in an arena subject to zoning restrictions, code requirements, and other government regulations, as well as credit markets and local labor and materials markets. They play important critical roles in characterizing, disseminating, and making decisions based on information about affordability of residential housing innovations.

\subsection{Suppliers}

Actors that supply owner-occupied housing in the United States include developers, builders, architects, material suppliers, product or assembly manufacturers, skilled tradesmen, and unskilled laborers. Developers, builders, and tradesmen typically operate within local geographic markets, while architects, material suppliers and product manufacturers may include organizations with a broader geographic presence.

Developers and their agents locate and identify land to be profitably converted into housing while navigating local land use rules. With the exception of custom homes, developers and builders make the preponderance of decisions concerning the home's design, systems, and materials and therefore have substantial discretion when it comes to adopting innovations. They specify to material suppliers and product manufacturers their needs and coordinate the skilled and unskilled labor required to construct the housing units.

The supplier category also includes those in the building trades involved in remodeling and renovation. But product innovators typically do not market to remodeling firms because this segment of the building industry is much more highly fragmented than home builders. The number of remodeling firms and their small size make individualized product demonstrations prohibitively time-consuming and costly for manufacturers. Remodeling firms, for their part, find that the information and training required to properly utilize and install innovative products are excessive in the absence of clear payoffs.

\subsection{Enablers}

Enablers are those who facilitate housing market transactions. They include mortgage lenders, insurers, realtors, inspectors, and appraisers. Lenders and insurers may operate over a large geographic area, while realtors, inspectors, and appraisers operate at the local, state, or regional level. These enablers are also sources of information to potential homebuyers about the type and condition of materials, components, designs, and systems used in homes on the market. Federal, state, and local government agencies that formulate or implement policies designed to increase access to home ownership are also enablers. 
Several financial innovations have improved housing affordability. Automated underwriting, for example, has by one estimate decreased closing costs by half a point (Whiddon, Hattis, and Leng, 2004). Another innovation is hybrid fixed/adjustable rate mortgages, in which the interest rate is fixed for a set period of time and then adjusted periodically afterward. An example of another financial innovation is a mortgage which allows homeowners and homebuyers to borrow more than the current value of the home in order to finance improvements or repairs to the home. Many industry analysts believe some financial innovations, such as credit scoring, low down payment mortgages, and interest-only mortgages, have resulted in an increase in homeownership in the United States (Max, 2005).

Financial innovations, however, may not improve housing affordability. Vigdor (2004) constructs a theoretical model in which the presence of liquidity constraints depresses the price of homes. He concludes that the model shows that innovations in mortgage lending that reduce these liquidity constraints lead to increased prices, which pushes higher homeownership rates down.

\subsection{Buyers}

Home buyers vary by demographic and socio-economic characteristics, preferences, access to information, and decision-making behavior. Studies have also shown that homebuyer behavior depends on homebuying experience. Noted in Whiddon, Hattis, and Leng (2004) is the observation that second-time home buyers, perhaps having experienced the consequences of their earlier decisions, are much more focused on fundamental characteristics of the home than are first-time homebuyers. Second-time homebuyers are also more likely to be first adopters of new technologies. Other studies suggest that people who buy newly constructed homes move more frequently and thus have shorter time horizons.

Mankiw and Weil (1989) examine the relationship between U.S. housing prices and demographic composition. They show that large demographic changes have been associated with fluctuations in housing demand. Changes in housing demand, in turn, were associated with swings in housing prices.

Empirical research has established that uncertainty in labor income and credit constraints are associated with a lower probability of homeownership (Diaz-Serrano, 2004). Studies also suggest that lower-income individuals have higher discount rates and shorter time horizons (Whiddon, Hattis, and Leng, 2004). These conclusions imply that lower-income individuals have a higher time preference and stronger preferences for receiving money earlier than later. For individuals with higher discount rates, adopting an innovation with high upfront costs and large but distant savings may not be perceived as cost effective. 


\subsection{Regulatory Environment}

The regulatory environment also affects the affordability and adoption of innovations in the residential construction industry. An example of a regulation that encourages adoption of an innovation may be land use policies that limit the land available for development. Such policies may spur innovations in sewer technology that enable denser housing development. Regulation may also dampen adoption of innovations if their novelty requires development of new testing procedures.

There are several forms of regulations that affect the affordability of residential housing and the adoption of new technologies. Zoning restrictions, zoning conversion procedures, and land use policies affect how assets can be used. ${ }^{2}$ Tax incentives policies have been used to encourage rehabilitation of older homes or conversion of existing structures from nonresidential uses. The Low Income Housing Tax Credit (LIHTC) is one example of a tax incentive to promote the development of affordable rental housing for low-income households. ${ }^{3}$ In 2005, the U.S. Senate considered the Community Development Homeownership Tax Credit Act, legislation which is intended to promote the construction of new housing or rehabilitation of existing housing to be sold to lowerincome families (U.S. Senate, 2005).

Building codes and code enforcement are regulatory devices often intended to serve life safety objectives. Burby, May, Malizia, and Levine (2000) argue, however, that such codes have contributed to the decline of urban areas by adversely impacting affordability. On the other hand, some jurisdictions offer developers incentives to construct affordable housing. In Montgomery County, Maryland, for example, developers of subdivisions with 50 or more units receive a bonus density in exchange for including affordable housing units within the development (Montgomery County Department of Housing and Community Affairs, 2001). Housing innovations may enable developers to satisfy life safety-based codes while preserving the affordable housing objectives of the mandates.

Finally, regulations of lenders, insurers, and other financial institutions affect the ability of potential buyers to purchase and own a home and to finance renovations and remodeling to incorporate newer technologies. Lenders, for example, face constraints on the types of loan products they can offer and portfolio limits. Insurers are subject to state-level regulations about coverage, premiums, and disclosure requirements. Regulations of both lenders and insurers affect the ability of individuals to purchase homes and of homeowners to secure financing for renovations and insurance for the improved homes. For example, on several occasions during the first half of 2005, both Federal Reserve Chairman Alan Greenspan and Treasury Secretary John Snow called on the U.S. Congress to tighten statutory limits on the portfolio holdings of governmentsponsored enterprises (GSEs) in mortgage financing due to concern about their exposure

\footnotetext{
${ }^{2}$ See, for example, Glaeser and Gyourko (2003), Glaeser and Gyourko (2002), Levine (1999). and Glaeser. Gyourko, and Saks (2005).

3 See http://www.hud.gov/offices/cpd/affordablehousing/training/lihtc/index.cfm, accessed on May 19, 2005, for details.
} 
to potential disruptions to market liquidity. ${ }^{4}$ In May 2005, the Office of the Comptroller of the Currency issued guidelines developed by several Federal banking regulators for mortgage lenders in response to rapid growth in home equity lending (Office of the Comptroller of the Currency et al., 2005). Insurance premiums are heavily regulated by each state, and while there are homeowner's insurance discounts for safety devices like fire extinguishers and smoke alarms, these reductions are modest compared to the overall premium.

See Snow (2005), Somerville (2005), Aversa (2005). Felsenthal (2005), and Greenspan (2005). Greenspan did suggest that such limits were unlikely to affect mortgage rates due to competition in the mortgage banking industry. 


\section{Innovations in Residential Construction}

Innovations in residential construction have affected the affordability of housing through their impact on first costs and on operations, maintenance and repair costs. Some innovations reduce the needed quantities of construction material, or enable the use of more cost-effective materials, both of which reduce the cost of construction. Some are designed to improve energy efficiency, reducing operating costs. Others involve materials or components of greater durability that require less frequent replacement. And still others improve the safety, convenience and desirability of a home. When innovations accomplish these objectives in a way apparent to subsequent potential home buyers, they also affect affordability through cost recovery at time of resale or lease.

This chapter describes key research on characteristics and diffusion of innovations, both generic innovations and those specific to the construction industry, and their effect on affordability. It describes a database of residential construction innovations that PATH, a private-public partnership which HUD sponsors, has identified as contributing to its goal of affordability. ${ }^{5}$ This chapter concludes with a discussion of critical barriers to the diffusion and acceptance of new technologies in owner-occupied homes.

\subsection{Characteristics and Diffusion of Innovations}

There are several characteristics that affect the adoption of innovations, one of which is cost. This section introduces these characteristics to provide background and context for the discussion in Chapter 4 of cost metrics. To understand metrics of affordability for supporting the diffusion and adoption of residential construction innovations in owneroccupied housing, it is important to describe the context in which these metrics will be used. While these metrics will facilitate decision-making about adoption of new technologies, there are other factors that affect diffusion and adoption. Rogers (1995) defines an innovation as "an idea, practice, or object that is perceived as new by an individual or other unit of adoption." He identifies five main characteristics of innovations which affect their diffusion:

1. Relative advantage - the degree to which an innovation is perceived as better than the idea that it supersedes.

2. Compatibility - the degree to which an innovation is perceived as being consistent with the existing values, past experiences, and needs of potential adopters.

3. Complexity - the degree to which an innovation is perceived as difficult to understand and use.

4. Triability - the degree to which an innovation may be experimented with on a limited basis.

5. Observability - the degree to which the results of an innovation are visible to others.

\footnotetext{
5 In addition to affordability, other PATH goals are: quality and durability: energy efficiency: environmental performance; and health, safety, and disaster resistance.
} 
These characteristics are strong predictors of the pace and extent of the diffusion of innovations. Greater relative advantage, compatibility, triability, and observability and lower complexity are associated with more rapid diffusion. Any cost savings due to new technologies increase their relative advantage, and the metrics developed in this report contribute to the quantification of an innovation's relative advantage.

Innovations can be classified in several ways. The concept of innovation applied traditionally to manufacturing has yielded product innovations, which improve the service of existing functions; functional innovations, which result in previously unavailable functionality; process innovations, which, in the context of building construction, improve the installation or production of residential housing components; and design innovations, which, for example, enable new uses for space or conserve on building materials. Product innovations, process innovations, and design innovations can yield cost savings by reducing material costs, labor costs, and operating, maintenance, and replacement costs.

Slaughter (1998) identifies five models of construction innovation: incremental, modular, architectural, system, and radical innovations. These innovations span a continuum in size of change from the current state-of-the-art or technology, from modest, incremental innovations to rare, breakthrough radical innovations.

Residential construction innovations can also be grouped by relevance to type of housing. Some may be practical for new construction only, and others may be better suited as retrofits for remodeling projects. Some innovations are better suited for multi-family housing, although this report focuses on single-family housing.

Researchers have identified four factors that affect the diffusion of technological innovations. ${ }^{6}$ They are: uncertainty among decision makers; lack of knowledge, or learning, about the existence and characteristics of innovations; dynamism and improvement of the new technology; and expected profitability, or financial consequences of adoption, for both the product manufacturers and for users. The affordability metrics that this report provides encourages diffusion by directly addressing the uncertainty, lack of knowledge, and financial consequence factors.

Diffusion of innovations occurs along several dimensions. One dimension is geographic. This type of diffusion is subject to the innovation's regional relevance. Local characteristics such as climate, density, income levels, or preferences may render some innovations better candidates for adoption than others. For example, a frost-protected shallow foundation is a climate-oriented innovation and is relevant primarily for homes in the northern United States.

Another dimension along which diffusion of an innovation can occur is market penetration. For innovations that are not geography-specific, market penetration is the relevant measure of diffusion. Examples include tankless water heaters, easy-installation flashing, and pre-cut studs.

\footnotetext{
${ }^{6}$ Stoneman (1983) and Mansfield (1995), cited in Chapman (2000).
} 
Diffusion occurs by housing type and by building classification. Some innovations are specific to single-family homes, while others, such as fire retardant or soundproofing materials, may be used more heavily in town homes or multi-family structures.

The building classification of a housing technology affects its diffusion by determining the potential for adoption at different stages of construction-related activity. These classes are building system, building component, or building material. For example, a new technology building system would more likely be incorporated during new construction, whereas a new technology building material could be adopted during new construction, an addition, or an alteration. Table 3-1 clarifies the relationship between the building classification of the new housing technology and the type of constructionrelated activity associated with it. A "+" symbol indicates that potential for adopting innovations classified according to that building classification at that stage of construction-related activity is favorable. A " 0 " indicates the potential is moderate or neutral, and a "-" indicates that the potential is unfavorable.

Table 3-1 Potential for Adopting an Innovation Classified by Building Classification and by Type of Construction-Related Activity

\begin{tabular}{|c|c|c|c|c|c|}
\hline \multirow{2}{*}{$\begin{array}{c}\text { Building } \\
\text { Classification }\end{array}$} & \multicolumn{5}{|c|}{ Type of Construction-Related Activity } \\
\cline { 2 - 6 } & $\begin{array}{c}\text { New } \\
\text { Construction }\end{array}$ & Additions & Alterations & $\begin{array}{c}\text { Major } \\
\text { Replacements }\end{array}$ & $\begin{array}{c}\text { Maintenance } \\
\text { and Repair }\end{array}$ \\
\hline System & + & + to 0 & 0 to - & 0 to - & - \\
\hline Component & + & + & + & 0 & - \\
\hline Material & + & + & + & 0 & 0 \\
\hline
\end{tabular}

In a comparison among industries, Ventre (1980) disputes the perception that the residential construction sector is technologically backward. Even in heavy industry, citing Mansfield, he notes that some cost-saving innovations did not become common practice for thirty years. Ventre extends Mansfield to the construction sector by devising a measure of technological diffusion for 14 early- to mid-century innovations in building practices. The metric is the cumulative number of local building codes that accommodate the new designs. By this measure, Ventre suggests that the pattern over time of diffusion in the construction industry denies "the technological lethargy of the building industry and the agencies that regulate it" (Ventre, 1980, pp. 318-319).

\subsection{PATH ToolBase Technology Inventory}

The PATH ToolBase Service, which is a resource for technical information about the housing industry provided by the National Association of Home Builders Research Center (NAHBRC), features a technology inventory ${ }^{7}$ of 174 residential construction innovations (Appendix B). The technologies which comprise the inventory were identified for promotion based on their anticipated contributions to PATH`s goals of

\footnotetext{
${ }^{7}$ http://www.toolbase.org/secondaryT.asp?CategoryID=1382
} 
affordability; quality and durability; energy efficiency; environmental performance; and health, safety, and disaster resistance. These innovations include parts, materials and components; assemblies; methods; and entire systems. The technologies identified as furthering PATH's goal of affordability provide a starting point for stakeholders who seek to improve the affordability of owner-occupied housing through the introduction of new residential technologies.

The technology inventory features innovations along four degrees of diffusion: on the horizon, emerging, mature, and graduate. Technologies that are on the horizon are those that are not yet necessarily commercialized, that may not have independent testing, and about which little is known. An example of such a technology is solar cooling, which involves solar-powered refrigeration and dehumidification. Currently, there are no commercially available solar absorption or desiccant cooling systems appropriate for residential application.

The technology inventory focuses on technologies that are emerging. Emerging technologies are those that have undergone limited commercialization and market penetration (no more than five percent market share), and for which there is minimal documentation. Window films that reduce energy loss through glass and block ultraviolet radiation are an example of an emerging technology.

Mature technologies are technologies which have greater market penetration and more extensive documentation, although there may still be barriers to adoption. An example of a mature technology is dry system hydronic radiant floor heating. This system pumps heated water through tubing under the floor, which radiates warmth. The high initial cost and inconvenience of retrofitting floors and performance considerations have affected their diffusion.

Finally, graduate technologies are those that are well documented and have substantial market penetration and acceptance. An example of a graduate technology is the programmable thermostat, which potentially reduces energy consumption by allowing more optimal timing of heating and cooling in a home.

Several innovations have been identified for field evaluations, demonstrations, and national pilot projects. Operating on various scales, these efforts promote the adoption of housing innovations by generating documentation about the application, installation, and performance of the technologies and evaluating the community-wide impacts of adopting the technologies.

PATH has furthermore identified ten high priority candidate technologies for their targeted technology transfer and diffusion effort (NAHB Research Center, 2003). These technologies are: frost protected shallow foundations, home-run plumbing systems, heating, ventilation and air conditioning (HVAC) optimization, tankless water heaters, air admittance vents, shared wastewater treatment, low impact development, integrated steel/wood combination framing, pre-cast concrete wall and foundation panels, and engineered panelized systems for walls and roofs. 


\subsection{Barriers to Adoption of Housing Innovations}

While inadequate affordability metrics are one key factor affecting the diffusion of innovations in residential construction, there are several other barriers to adoption (Building Technology Incorporated, 2005). These barriers can be grouped into two broad categories: (1) information gaps and uncertainty and (2) vested interest in the status quo. ${ }^{8}$ Practical and credible affordability metrics will go far in alleviating both types of barriers.

Many stakeholders play pivotal roles in the acceptance or rejection of residential construction innovations: final consumers, builders, building contractors, regulators, ${ }^{9}$ product manufacturers, and materials suppliers. Realtors, appraisers, insurers, and lenders are other stakeholders who have the potential to affect the use of innovations in owner-occupied homes. Besides acceptance or rejection, responses can also take the form of inaction or apathy on the part of one or more stakeholders. Metrics that allow these stakeholders to evaluate the affordability of residential housing innovations will bridge the information gaps facing stakeholders and address their vested interests.

Information gaps and uncertainty occur in several contexts. They occur with respect to who bears the costs of utilizing an innovation relative to who accrues the benefits, and who bears liability for failures, whether manufacturers, laboratories, or builders. They occur with respect to the visibility of the innovation and its benefits; between homeowners or, for new construction, homebuilders and potential buyers; among realtors and appraisers; and between product manufacturers and home builders.

Stakeholders also have vested interests which affect their response and receptiveness to innovations in the residential construction industry. For example, contractors and tradesmen have a vested interest in preserving the marketability of their skills. New technologies that make these skills obsolete are seen as a threat to their livelihood. In a case like this, this stakeholder group may discourage homeowners from choosing new technologies.

Table 3-2 describes both categories of barriers as they apply to each group of stakeholders. Identifying and characterizing these barriers is essential to developing direct methods to address and mitigate them. For example, for new technologies such as those described above that require additional skills for installation, manufacturers may offer training for tradesmen. Only by identifying these barriers is it possible to develop solutions to overcome them.

\footnotetext{
${ }^{8}$ At the June 4-5, 2003 workshop, participants raised a number of barriers to adoption, which the author of this report has classified into these two categories.

${ }^{9}$ At the June 4-5, 2003 workshop, participants discussed the appropriateness of including regulators as a category of stakeholders. Those reluctant to treat them as stakeholders noted that their interest in life safety aligns with that of the housing occupant. One point in favor of treating regulators as stakeholders is that their agendas may diverge from those of owner-occupants. See Hattis. Whiddon and Leng (2003).
} 


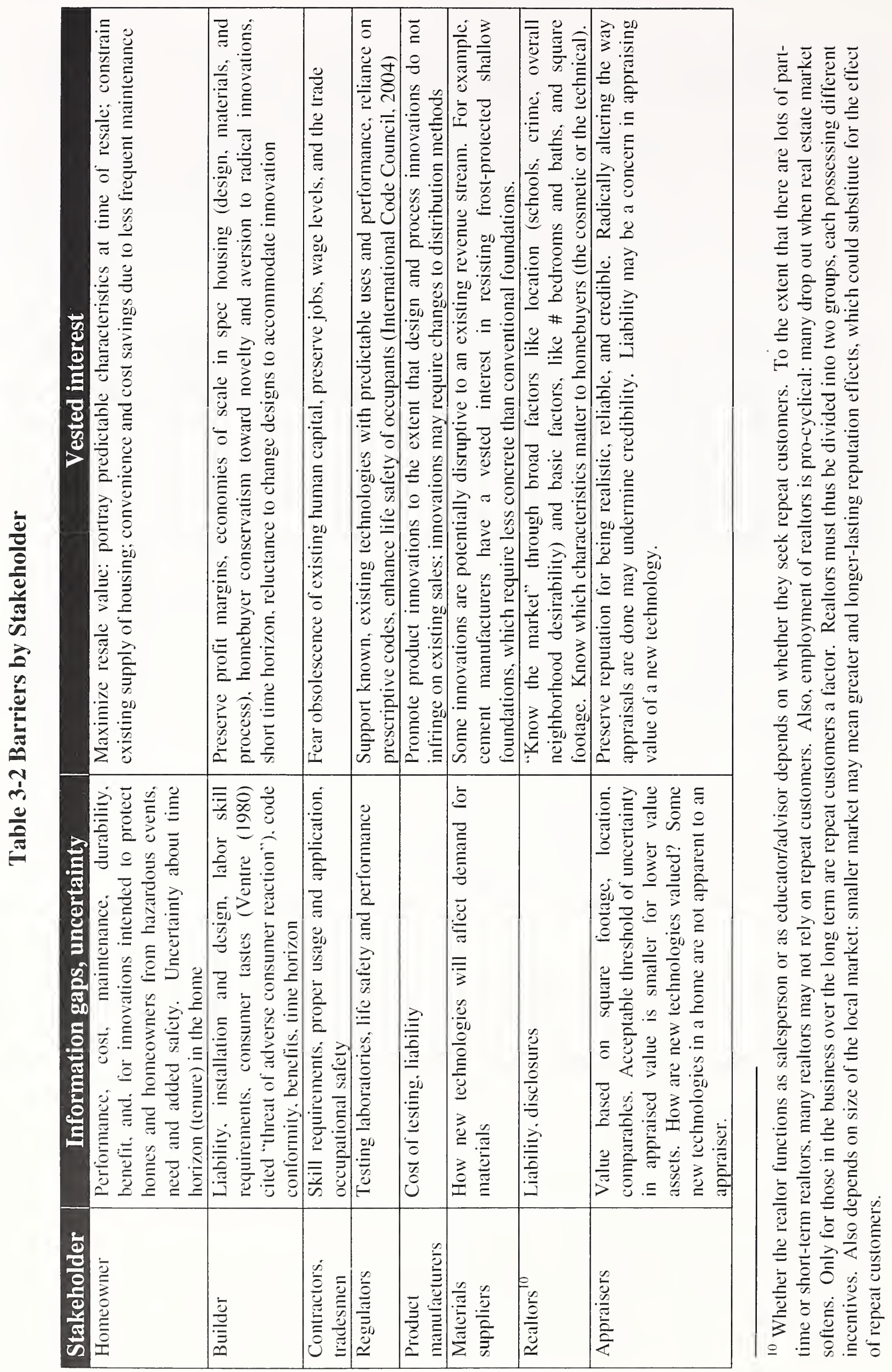




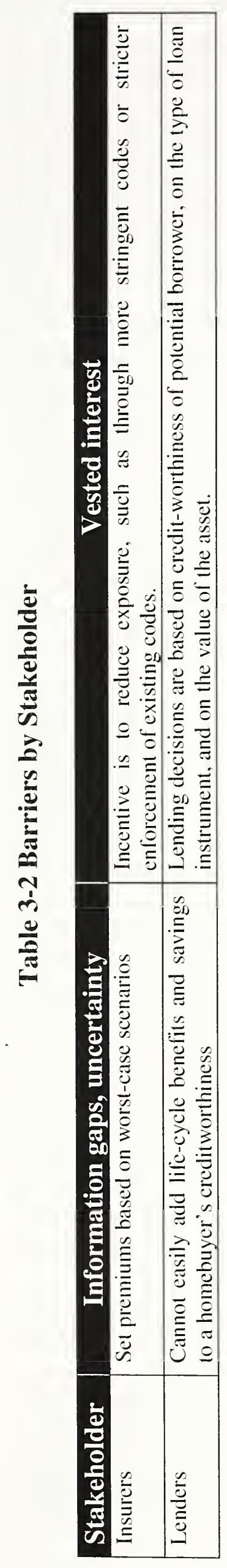




\section{Measuring the Affordability of Residential Building Innovations: A Methodology}

Developing and disseminating a methodology to assess the affordability of new technologies in housing are key steps to addressing many of the barriers to new technology adoption described in Chapter 3. This chapter presents methods to measure the affordability of a new technology. Chapter 5 addresses the second step by proposing a roadmap for disseminating these metrics.

The cost of a new technology for an owner-occupied home consists of several components: the initial cost of the device, material, machinery, or equipment; cost of incorporating the technology into the design; installation costs; operating and maintenance costs; energy consumption costs; replacement costs; and disposal costs (or salvage value). For technologies designed to improve safety or reduce damages from hazardous events, the savings from avoided losses also figure into the cost equation as a benefit. These costs are incurred at different points in time, and apply at different stages of construction. Decision makers compare these costs for a new technology with those for an incumbent technology over a relevant time period (also called a study period) to make a cost-effective choice. When an innovative technology reduces costs, that innovation improves housing affordability.

This chapter is organized as follows: Section 4.1 introduces affordability concepts and metrics and some cost issues related to adoption of innovations. Section 4.2 relates these affordability metrics to specific stakeholders. Section 4.3 presents a schematic for organizing the proposed affordability metrics. Finally, section 4.4 describes factors other than cost that enter into decision making about adoption of residential housing innovations.

\subsection{Proposed Affordability Metrics}

The affordability of a new technology can be measured in several ways. The most straightforward measurement is first cost. Often thought of as the key determinant of a new technology's affordability, first cost is comprised of the initial cost of equipment and materials and labor for installation. In the case of replacing a traditional water heater with a tankless water heater, for example, the first cost would be the purchase price of the tankless unit in addition to the cost of installing and, if necessary, reconfiguring the plumbing and vents to accommodate the new water heater. To choose a technology based on first cost is straightforward: compare the first costs of two different technologies and choose that with the lower value.

Complicating this comparison is that the first costs of new technologies sometimes fall as the technology diffuses. This cost reduction can occur for several reasons. First, as greater numbers in the skilled trades become familiar with the new technology, labor installation costs may fall. Second, after a new technology has been introduced, over time, other manufacturers may develop and bring to market similar alternatives. The competition from these products can drive down the price of the new technology. Third, as the market grows with diffusion of the new technology, the manufacturer may 
experience scale economies, whereby doubling the scale of production increases costs by less than double. Finally, if a manufacturer becomes more experienced in producing the new technology, it may find efficiencies that improve the production process, reducing manufacturing costs. Whether the last two scenarios, in which manufacturing costs fall, result in reductions in the prices paid by consumers depends on the structure of the market for the new technology.

For most technologies, there are other costs associated with their ownership and operation not captured by first cost. In the tankless water heater example, such expenditures include energy costs. Life-cycle cost allows a decision-maker to take into account the stream of these other costs over the time period of interest. Life-cycle cost incorporates first cost, energy costs, operations and maintenance (O\&M) costs, replacement costs, and disposal costs or salvage value (Fuller and Petersen, 1996). It is a metric with well established foundations in ASTM Standard Practice E 917 (ASTM International, 2002b) .

Two additional factors in the computation of life-cycle cost are the study period and the discount rate. The study period refers to the time period of concern, such as the time period during which the decision maker must pay the costs associated with the innovations. For homeowners, for example, the study period may be the period of time until the house is sold. The discount rate is used to convert future dollar streams into present value terms. Discounting is used in order to take into account the time value of money. ${ }^{11}$

Decision makers can use life-cycle cost analysis to decide whether to make a capital investment or to choose among investment sites or design alternatives. Life-cycle cost analysis can also incorporate the impacts of residential building innovations on safety and disaster mitigation through expected losses reduced and avoided over the period of interest. Homeowners or prospective home buyers can use life-cycle cost analysis to compare the costs of residential housing innovations with the costs of maintaining their current systems based on a specified study period and the appropriate discount rate.

Life-cycle cost is computed according to Equation 4-1. T refers to the study period. For homeowners, $T$ can refer to the period of time they own the home. The subscript $X$ refers to technology $X$, and the subscript $S$ refers to the stakeholder group. The first cost of technology $X$ is incurred in period 0 , the initial period, but subsequent costs must be adjusted by the discount rate. Every cost associated with owning and operating technology $X$ that the decision maker must pay during $T$ is included in this metric: operations and maintenance costs, repair costs, replacement costs, and disposal costs. If the technology has salvage value, that salvage value enters the life-cycle cost equation as a negative value for disposal cost. ExpectedLoss $X_{X}$ is a term that takes into account the uncertain losses associated with technology $X$ during period $t$. Sources of uncertainty include weather hazards or reliability of a housing product. An example of losses is

\footnotetext{
${ }^{11}$ Fuller and Peterson (1996) discuss the concept of the time value of moncy and the need for discounting. They also describe techniques used to discount dollar streams into a present valuc. See pages 3-1 through $3-16$.
} 
damage due to weather hazards or failure of material, equipment, or system used in the home. ExpectedLoss ${ }_{X t}$ is computed as the probability of that loss during time $t$ multiplied by the loss, in dollars.

(Equation 4-1)

$$
\mathrm{LCC}_{X_{S}}=\text { First } \operatorname{cost}_{X_{S}}+
$$

$$
\sum_{t=0}^{T_{S}}\left[\frac{\text { O\&M }_{X_{S t}}+\text { Repair }_{X_{S t}}+\text { Replacement }_{X_{S t}}+\text { Disposal }_{X_{S t}}+\text { ExpectedLoss }_{X_{S t} t}}{\left(1+\text { discount rate }_{S}\right)^{t}}\right]
$$

where $X$ $=$ technology $X$,

$S \quad=$ stakeholder group (either takes a value of $H$ to indicate homeowner or a value of $B$ to indicate homebuilder),

$\mathrm{LCC}_{X_{S}} \quad=$ life-cycle cost of technology $X_{S}$,

First $\operatorname{cost}_{X_{S}} \quad=$ purchase and installation cost of technology $X$ incurred during the initial period (see Equation 4-3),

$O \& \mathrm{M}_{X_{s} t} \quad=$ operations and maintenance cost of technology $X$ during period $t$,

Repair $_{X_{S^{t}}} \quad=$ cost to repair technology $X$ during period $t$,

Replacement $_{X_{S t}}=\cos$ to replace technology $X$ during period $t$,

Disposal $_{X_{S} t} \quad=$ cost to dispose of technology $X$ during period $t$ (salvage value of technology $X$ enters as a negative value for disposal cost),

ExpectedLoss $_{X_{S t}}=$ cost related to technology $X$ that stakeholder $S$ bears during period $t$ due to natural hazard, accident, or other uncertain event multiplied by the probability of that event,

discount rate $_{S}=$ a value between 0 and 1 that is the rate at which stakeholder $S$ discounts each dollar from one time period to the next, and $T_{S} \quad=$ study period for stakeholder $S$. indexed by the subscript $t$.

To compare the life-cycle cost of technology $X$ with that for technology $Y$ requires performing a similar computation for technology $Y$ and comparing the two values for lifecycle cost. The technology associated with the lower life-cycle cost is more affordable. The difference between the two is the present value of net savings (PVNS) for each stakeholder $S$, and is given in Equation 4-2.

(Equation 4-2)

$\mathrm{PVNS}_{Y_{S}}=\mathrm{LCC}_{X_{S}}-\mathrm{LCC}_{Y_{S}}$,

where $\mathrm{PVNS}_{Y X_{S}}$ is the present value of net savings of technology $Y$ over technology $X$ for stakeholder $S$. Technology $Y$ is more cost-effective or affordable than technology $X$ if 
$\mathrm{PVNS}_{Y X_{\varsigma}}$ is positive. If $\mathrm{PVNS}_{Y X_{s}}$ is negative, then technology $X$ is more affordable than technology $Y$.

First cost is computed according to Equation 4-3. It is a special case of the life-cycle cost in Equation 4-1. For first cost, $T$ equals zero, because first costs are defined as those incurred during the base date. When $T$ equals zero, the entire second term, given by the summation of the term in square brackets, also equals zero and thus drops out.

(Equation 4-3)

First $\operatorname{cost}_{X_{S}}=$ Purchase $\operatorname{cost}_{X_{S}}+$ Installation $\operatorname{cost}_{X_{S}}$.

When comparing the first costs of two technologies, $X$ and $Y, Y$ is the more affordable technology if Equation 4-4 holds.

$\Delta$ First $\operatorname{cost}_{Y X_{S}}=$ First $\operatorname{cost}_{X_{S}}-$ First $\operatorname{cost}_{Y_{S}}>0$.

(Equation 4-4)

\subsection{Proposed Metrics for Measuring Affordability, by Stakeholder}

Life-cycle cost can be computed for each stakeholder. The relevant costs for each stakeholder are those that the stakeholder must pay. When homeowners purchase a home, for example, they receive the remaining service life of the building components of the home (Whiddon, Hattis, and Leng, 2004). They also pay for the resources that the home utilizes, such as energy, water, and sewage. If the homeowner's tenure in a home exceeds the service life of its components, then the homeowner must also pay for replacement with a new component and disposal of the expired component. The period of time a homeowner occupies the home is often used as the study period. Equation 4-5 below describes the life-cycle cost for a new technology for homeowners, denoted by subscript $H . T_{H}$ is the number of years the homeowner lives in the home, and discount rate $_{H}$ is the discount rate applicable to homeowners.

$\mathrm{LCC}_{X_{H}}=$ First cost $X_{H}+$

(Equation 4-5)

$$
\sum_{t=0}^{T_{H}}\left[\frac{\text { O\& }_{X_{H^{t}}}+\text { Repair }_{X_{H^{t}}}+\text { Replacement }_{X_{H^{t}}}+\text { Disposal }_{X_{H^{t}}}+\text { ExpectedLoss }_{X_{H^{t}}}}{\left(1+\text { discount rate }_{H}\right)^{t}}\right]
$$

Builders, on the other hand, typically have a much shorter study period. Their study period begins with the purchase of land or property and ends once the newly constructed home is sold. For most builders, this study period is fewer than two years. Their interest is in profiting from their choices about building materials, designs, and systems when the home is sold. For homes that are sold before construction is completed, the new (future) homeowners can make some choices from available options and upgrades. But often builders make decisions based on their assessment of consumer tastes and preferences to more quickly and profitably sell the homes. The costs that enter into a builder's affordability calculation for new technologies are material and equipment cost, design 
cost, and installation cost less the marginal increase in the selling price of the home. Many builders do not pay for energy costs, water consumption costs, waste disposal costs, or replacement costs, but will take these costs into account when making decisions about materials or equipment choices if they believe doing so is profitable. The discount rate for builders, discount rate $_{B}$, is often different from the discount rate that applies to homeowners because the two stakeholder groups have different time values of money. Equation 4-6 specifies the computation of life-cycle cost for homebuilders, where the subscript $B$ indicates builder.

$$
\begin{aligned}
\mathrm{LCC}_{X_{B}}= & \text { First cost } \\
& \sum_{t=0}^{T_{B}}\left[\frac{\mathrm{O \& M}_{X_{B} t}+\text { Repair }_{X_{B} t}+\text { Replacement }_{X_{B} t}+\text { Disposal }_{X_{B} t}+\text { ExpectedLoss }_{X_{B} t}}{\left(1+\text { discount }_{\text {rate }}\right)^{t}}\right]
\end{aligned}
$$

\subsection{Proposed Metrics for Measuring Affordability by New Construction vs. Existing Housing}

In section 4.1, the concept of life-cycle cost was introduced. Section 4.2 described how life-cycle cost was computed for different stakeholders. This section provides further distinctions in the application of first cost and life-cycle cost by exploring the differences between newly constructed homes and existing housing.

First costs and life-cycle costs of new housing technologies differ for new construction than from those for existing construction. Figure 4-1 depicts these combinations. The first dimension is new construction versus existing housing, and the second dimension is first cost versus life-cycle cost. The discussion below addresses technical metrics for each of the four combinations. The roadmap in Chapter 5 will include discussion of barriers to the dissemination and implementation of the proposed metrics.

Figure 4-1 Affordability Metrics for New Construction and Existing Housing

New Construction Existing Housing

\begin{tabular}{|l|l|l|}
\hline \multirow{2}{*}{ First Cost } & $A$ & $B$ \\
\hline Life-cycle Cost & & \\
\cline { 2 - 3 } & $C$ & $D$ \\
& & \\
\hline
\end{tabular}


In the first dimension, housing is divided into two categories: new construction and existing housing. Housing is divided into these two groups to distinguish between the differing types of decisions and costs. For example, with new construction, decisions about design, materials, systems, or components are typically made before construction begins. With existing housing, on the other hand, these choices are made after legacy materials, components, and systems have already been installed. Adopting an innovation requires costs for demolition, remodeling, disposal and replacements. These additional steps add to the costs associated with incorporating an innovation into an existing home. Another key factor for treating new construction separately from existing construction is that some decisions may not be applicable or feasible for existing construction and only apply to new housing. Frost-protected shallow foundation is an example of such a technology.

The second dimension of the schematic is based on cost: first cost versus life-cycle cost. First cost is one approach to evaluating affordability. For existing construction, first cost includes demolition and re-design costs and the value of loss of use of the area being upgraded. The first cost for residential construction innovations in the case of new construction is the difference in the price to purchase or build (for custom homes) the home that the homebuyer must pay. In the case where the homeowner is deciding to replace materials, components, or systems in the home he or she already occupies, the first cost of these innovations is the cost of the new materials, parts, or systems and labor installation of the innovation, as well as the costs of demolishing and disposing of the existing materials, components, or systems.

First-cost affordability is a critical metric for several stakeholder groups. Homebuyers and builders may see the selling price of a home as the key determinant of whether or not that home is affordable. Lenders are concerned that the selling price of the home does not exceed appraised value of the home.

A second approach to evaluating overall housing affordability is based on life-cycle costing, represented by $\boldsymbol{C}$ and $\boldsymbol{D}$ in Figure 4-1 and as described in Equation 4-1. The lifecycle cost-oriented definition of affordability also incorporates the risks and uncertainties associated with homeownership, such as damage or losses from hurricanes, earthquakes, or flooding. Examples of ways to improve housing affordability defined in this way include using more durable or energy-efficient building materials or components, designing and building for lower maintenance, and use of passive, more "fool-proof" risk mitigation devices.

Table 4-1 summarizes the affordability metrics for new construction and for existing housing based on the combinations introduced in Figure 4-1. Table 4-1 specifies the type of information that is needed to compute the first cost and life-cycle cost for each type of housing to facilitate the efforts of homeowners and homebuilders in comparing the costeffectiveness, or affordability, of two or more residential construction innovations. The affordability metric is the difference between the firsts costs of technology $Y$ and technology $X$, or the present value of net savings of technology $Y$ over technology $X$. If 
the difference in first cost or if the present value of net savings is positive, then technology $Y$ is more affordable than technology $X$.

\section{Table 4-1 Summary of Cost Components for Residential Construction Innovations}

\begin{tabular}{|c|l|l|l|}
\hline \multicolumn{1}{|c}{ Type } & \multicolumn{1}{c}{ Usage } & \multicolumn{1}{c|}{ Affordability Metric } \\
\hline A & New construction & Difference in first cost & Purchase and installation costs \\
\hline B & Existing housing & Difference in first cost & $\begin{array}{l}\text { Purchase, redesign, and } \\
\text { installation costs }\end{array}$ \\
\hline C & New construction & $\begin{array}{l}\text { Present value of net } \\
\text { savings (Equation 4-2) }\end{array}$ & $\begin{array}{l}\text { First cost for Type A plus } \\
\text { operation, maintenance, and } \\
\text { disposal or resale costs over } \\
\text { relevant time period. }\end{array}$ \\
\hline D & Existing housing & $\begin{array}{l}\text { Present value of net } \\
\text { savings (Equation 4-2) }\end{array}$ & $\begin{array}{l}\text { First cost for Type B plus } \\
\text { operation, maintenance, } \\
\text { replacement, and disposal or } \\
\text { resale costs over relevant time } \\
\text { period. }\end{array}$ \\
\hline
\end{tabular}

Type $\boldsymbol{A}$ in Table 4-1 shows what costs to include when determining first costs in the case of new construction. With new construction, home buyers are purchasing the entire service life of the home and its systems. Furthermore, many of the decisions regarding the design, size, materials, construction methods, and systems of the home were made by builders. Homebuyers may have some options to customize the home with upgrades, such as in floor coverings, window designs, lighting and plumbing fixtures, and cabinet and countertop surfaces. But most of the decisions fundamental to the home, such as type of piping used for plumbing, model of HVAC system, number of rooms, and type of water heater, are made by the builder. And if potential purchasers signal that first costs are a deciding factor in the buying decision, builders may select less expensive systems, materials, and methods to satisfy the demands of their market for lower first cost.

Type $\boldsymbol{B}$ in Table $4-1$ shows what costs are included in the first cost metric for existing housing. Measurement in this case is based on the selling price of the home. Unlike new construction, however, opportunities for customization are not typically included as a condition of the sale. In this case, the home buyer is mostly purchasing a home as-is ${ }^{12}$, with any desired customization performed after completion of the sale. With existing housing, home buyers are purchasing the residual service life of the home's roof, windows, siding, foundation, systems, fixtures, and appliances. Furthermore, the maintenance history of the home may be uncertain, depending on the age of the home, the number of previous owners or occupants, and the consequences of deferred maintenance. However, for first cost, remaining service life and maintenance history are not factors, except to the extent that they affect selling price. Selling price for existing housing depends on location, home and lot size, observable condition, age, and interior and exterior features (such as style, surface materials, and layout).

\footnotetext{
${ }^{12}$ Home inspection contingencies in contracts are one exception.
} 
Type $C$ in Table 4-1 describes what costs are used to compute the present value of net savings based on life-cycle costing in newly constructed homes. With new homes, home buyers have options over a range of features. For completely custom homes, they may select the lot, orientation of the home on the lot, total square footage of the structure, floor plan, systems, and materials, subject to satisfaction of local building codes. With life-cycle costs as the relevant metric, consideration may be given to systems that have higher initial costs that yield cost savings over the study period. These cost savings may accrue due to reduction in energy consumption, less frequent replacement or maintenance, or greater reliability. In areas subject to earthquakes, flooding, high winds, and natural hazards, cost savings may also be realized through reductions in expected losses or a lower premium for hazard insurance. For features that are visible, future buyers may value them sufficiently to pay a premium for the remaining service life on these systems, allowing the homeowner to partially recover the capital investment.

Type $\boldsymbol{D}$ in Table 4-1 refers to the application of present value of net savings in life-cycle costs to existing homes. Unlike Type $\boldsymbol{B}$, which is first-cost oriented, the condition and efficiency of the home become more prominent with Type $\boldsymbol{D}$, as additional cost factors are considered in the life-cycle cost metric. As described in Equations 4-3 (for homeowners) and 4-4. (for homebuilders), the cost factors include schedule and magnitude of expenditures for systems repairs and replacements, durability of the home's existing materials and systems, health and safety factors (such as the presence of lead paint or asbestos tiles, or hazard mitigation devices like storm shutters), resource requirements (such as electricity and water), and cost recovery at resale.

Simmons, Kruse, and Smith (2002) explore the effects on sale price of two types of hurricane mitigation in housing - retrofit through storm blinds and wind-resistant construction. Their models show that a home with storm blinds sells at a 5 percent premium compared to similar homes with no storm blinds, implying near complete recapture of retrofit costs. Similarly, a higher rating on the Structural Integrity Index (SII), which is an indicator of a structure's wind resistance based on its frame, roof, walls, and other environmental and structural parameters, is associated with a positive effect on selling price.

One technique for capturing the components of life-cycle costs over a specific study period is a cash flow diagram. Figure 4-2 illustrates, for the case of a newly constructed home, the type of information such a diagram contains and how this information is represented. Some expenses, such as investments and replacements, occur in specific years, while other costs recur annually. In Figure 4-2, the study period lasts 20 years. Initial investment in equipment with a 13-year service life occurs during the base date. A complete replacement occurs at the end of year 13. Over the 20-year study period, the investment incurs annual energy costs and operations and maintenance (O\&M) costs. At the conclusion of the study period, the owner receives the residual value of the investment, or the value of the remaining 6 years of service life. The dollar amounts specified in Figure 4-2 are in constant dollar terms. These dollar values need to be 
converted into present values by using the appropriate discount factors to compute the present value life-cycle cost. ${ }^{13}$

Figure 4-2 Sample Cash Flow Diagram for Homeowners, Case C: New Construction

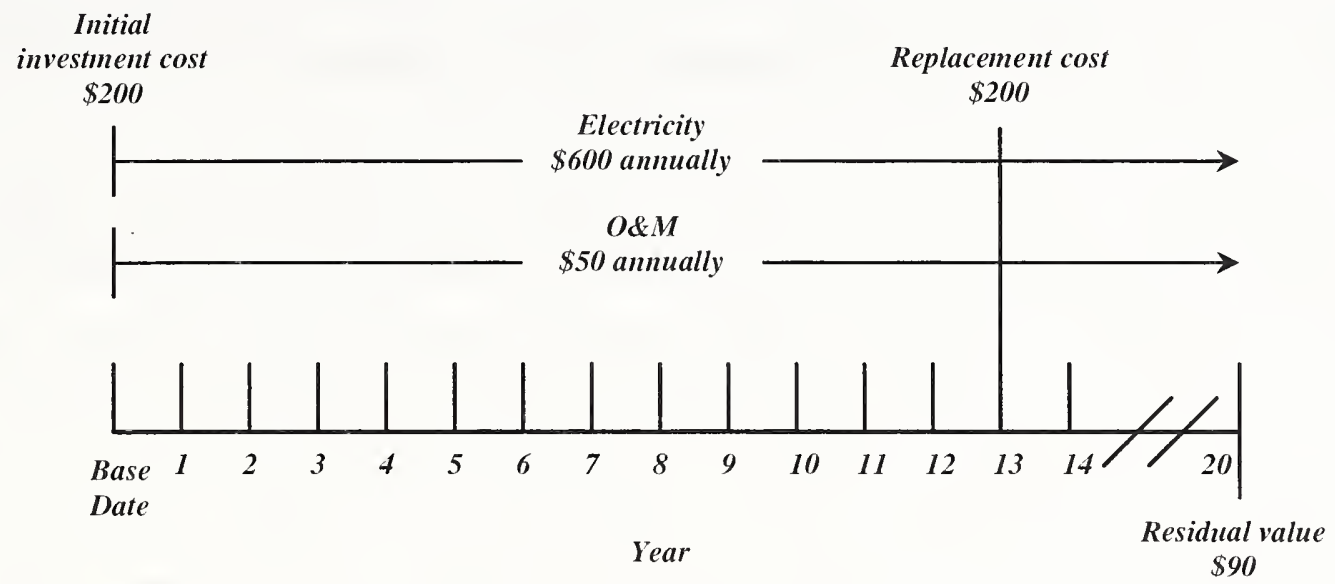

Figure 4-3 illustrates a sample cash flow diagram for an existing home. Like Figure 4-2, dollar values are in constant dollar terms. In this example, the home and the component of interest are both 12 years old. Because the service life of the component is only 13 years, the first replacement must take place during year 1, instead of year 13. A second replacement must take place during year 14. At the conclusion of the study period, the residual value of the equipment is based on 7 remaining years of service life.

\section{Figure 4-3 Sample Cash Flow Diagram for Homeowners, Case D: Existing Construction (12 year-old home)}

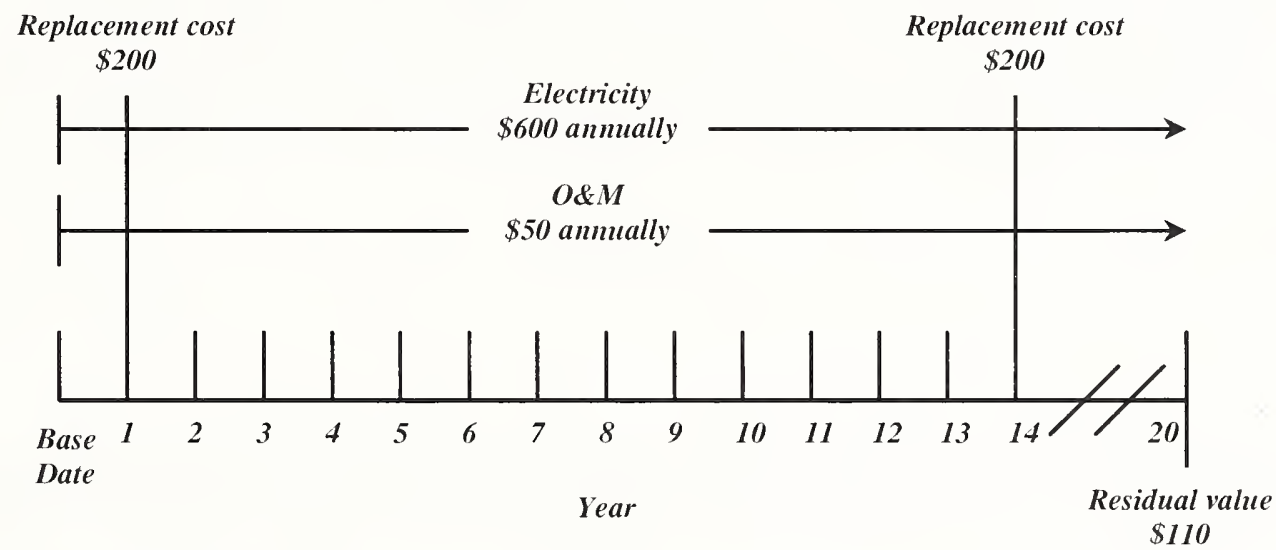

\subsection{Other Considerations}

First cost, life-cycle cost, the difference in first costs, and the present value of net savings help us measure the affordability of housing innovations and can be adapted for various stakeholders. But innovations can have benefits and drawbacks that are not easily quantified into dollars. Examples of these benefits and drawbacks are convenience to homeowners, added or reduced functionality or reliability, safety and disaster resistance,

\footnotetext{
${ }^{13}$ For a description of how to perform this discounting procedure. see Chapter 3 of Fuller and Peterson (1996), pp. 3-1-3-16.
} 
aesthetic qualities, and environmental performance. Some, such as aesthetic qualities, may also accrue in the form of spillovers to parties other than the decision maker. For exterior aesthetic benefits, for example, neighbors benefit even if they had no role in making the decision to improve the appearance. ${ }^{14}$ Even if they are difficult to quantify, the hard-to-monetize spillover benefits and costs of such innovations should be considered in conjunction with the more explicit life-cycle cost analysis of individual innovations.

These characteristics suggest an even broader perspective on housing affordability that, while beyond the scope of this report, merits acknowledgment. According to this perspective, evaluating housing affordability requires consideration of a broader range of housing characteristics. These considerations include health and safety benefits; location-related characteristics, such as crime; school quality; commuting time; and convenience to local amenities, as well as home-specific characteristics, such as home and lot sizes, amenities, and aesthetics. Although the benefits of some of these characteristics are difficult to quantify, they nevertheless factor into a prospective homebuyer's decision about the home's desirability, and are likely to affect the home's first cost (selling price).

Incorporating such a range of housing characteristics involves a multi-attribute approach. ASTM Standard Practice E 1765 (ASTM International, 2002a) offers a methodology for the application of Analytical Hierarchy Process (AHP), a type of multiattribute decision analysis, to investment decisions in buildings and building systems. ASTM also offers a software adjunct that helps owners make technology choices in the face of uncertainty and when dealing with multiple objectives (ASTM International, 1998). With regard to disaster resistance and safety, Kunreuther, Meyer, and Van den Bulte (2004) report on a simulation of homeowner decisions living in a fictional earthquake-prone area. They examine approaches to dealing with low probability, high consequence events by discussing the interactions among risk assessment, risk perceptions, and risk management.

\footnotetext{
${ }^{14}$ An exception is the role that some homeowners' associations (HOAs) play in approving architectural changes to homes within a community.
} 


\section{Roadmap for Dissemination of Affordability Metrics}

This roadmap describes steps to disseminate technical metrics for the affordability of owner-occupied housing, building on the inclusion of affordability in the International Residential Code (IRC). The efforts that the roadmap prescribes will be based on existing data, information, and research about the introduction, penetration, and valuation of technology in the housing stock. The resulting roadmap will provide guidance for policymakers, code officials, manufacturers, builders, and homeowners on the measurement and assessment of technology and durability for housing affordability. The challenge of the roadmap is to describe an approach that these key stakeholders can take to disseminate the affordability metrics described in Chapter 4 to potential homebuyers and the appraisers, inspectors, lenders, insurers, and real estate professionals whose actions can influence a buyer's home purchase decision.

A secondary goal of the roadmap is to propose ways that these metrics may be used to promote the technology advancement goals of PATH. With metrics to communicate the value of specific residential construction innovations, home buyers and homeowners will more quickly adopt newer technologies in their homes.

The roadmap focuses on the most constraining bottlenecks to dissemination and acceptance identified in this report. These approaches must achieve legitimacy through buy-in from key stakeholders. The roadmap focuses on promoting understanding and acceptance of the affordability metrics by homeowners and homebuyers to reduce the uncertainty and information gap facing consumers. Once homeowners accept the affordability metrics for new residential technologies, their attitudes and choices will influence and drive acceptance by homebuilders and remodelers. The roadmap then defines roles for lenders in promulgating affordability metrics. Finally, it offers suggestions to improve acceptance of new technologies among local code officials and valuation by appraisers.

Table 5-1 contains a summary of the methods of dissemination that this roadmap proposes; the methods are elaborated in the sections that follow.

Table 5-1 Summary of Methods of Dissemination, by Stakeholder

\begin{tabular}{|l|l|}
\hline Stakeholder & Method of Dissemination \\
\hline $\begin{array}{l}\text { Homeowners and } \\
\text { homebuyers }\end{array}$ & $\begin{array}{l}\text { Develop straightforward informational tools; focus on early } \\
\text { adopters. }\end{array}$ \\
\hline $\begin{array}{l}\text { Homebuilders and } \\
\text { remodelers }\end{array}$ & $\begin{array}{l}\text { Symbiotic exchange of information with homeowners and } \\
\text { homebuyers }\end{array}$ \\
\hline Lenders & Higher appraised valuations \\
\hline $\begin{array}{l}\text { Code-setting and } \\
\text { code-enforcement } \\
\text { community }\end{array}$ & $\begin{array}{l}\text { Training, top-down approach by model code organizations, } \\
\text { principles of evaluating new technologies for code compliance. }\end{array}$ \\
\hline Appraisers & $\begin{array}{l}\text { Provide guidelines for valuation of new technologies, with } \\
\text { dissemination in print in appraisal professional publications and } \\
\text { through training at professional society annual meetings. }\end{array}$ \\
\hline
\end{tabular}




\subsection{Reduce Uncertainty and Information Gap Facing Consumers}

When it comes to new technologies, some researchers categorize consumers as falling into one of three categories (Whiddon, Hattis, and Leng, 2004): early adopters who are risk takers and strongly prefer novelty; second-stage, intermediate adopters who are moderately open to novelty and who imitate the early adopters; and finally, homeowners more averse to novelty and resistant to change. There are suggestions that most consumers fall into the last category. Nevertheless, for new technologies to penetrate the marketplace, homeowners in the last category must be among the adopters.

It is essential to reduce the information gaps and uncertainty facing consumers without promoting specific technologies or products. Informing consumers about the cost implications of using specific technologies may appeal to consumers' wallets by drawing attention to reduced life-cycle costs. Tools such as the NEST software allow consumers to compare durability and life-cycle costs for major components of housing. ${ }^{15}$ The Energy Star brand enables consumers to make decisions about appliance purchases based on expected energy consumption. ${ }^{16}$ The challenge is to broaden the range of components and appliances in housing units that can be analyzed with such tools and designations. A further challenge is to develop tools and designations that are sufficiently straightforward to encourage widespread use. Tools that have inordinate information and computation requirements will limit utilization.

One suggested informational tool is a durability rating system (Whiddon, Hattis, and Leng, 2004). Such a system would reduce to one clear metric the overall durability of each home. The simplicity and clarity of the durability rating system would enable quick and straightforward comparison among homes, and give the information to potential homebuyers in an easily understood fashion. An analogy may be an individual's credit score. There are, however, practical considerations in reducing all facets of a home to one number. The issues of how various factors affecting a home's overall durability would be weighted and which entity is perceived as sufficiently impartial and credible to be tasked with determining each home's rating remain.

Another approach may be to focus on early adopters. If innovations penetrate sufficiently in this population and convey demonstrable benefits (particularly if these benefits accrue in the short term), then these "success story" anecdotes could be publicized more broadly among the imitators and the general population of homeowners. In other words, leveraging the influence of those who are most receptive to innovations may accelerate adoption of innovations by those who are typically less receptive. A generalization of

\footnotetext{
${ }^{15}$ The National Economic Service-life Tools (NEST) software at http://www.pathnet.org/sp.asp?id=9710 was developed for PATH by the Office of Applied Economics of the NIST Building and Fire Research Laboratory. NEST helps homeowners evaluate the tradeoff between durability of housing components and materials and their first cost and life-cycle cost.

${ }^{16}$ Energy Star provides testimony to the importance of the medium for dissemination. In the case of Energy Star, fact sheets resulted in limited responsiveness. When dissemination was switched to CDROMs, a medium which builders could customize to their competitive advantage, the Energy Star brand took off (Whiddon. Hattis, and Leng. 2004, p. 42).
} 
this approach is to segment the market of consumers based on wants and needs, and prioritize dissemination efforts accordingly.

Implicit in these approaches is the need to accept the limitations of a "push" strategy in which supply implicitly creates demand. There is a need to focus on "pull"; innovation must satisfy an existing "itch." Outreach and information could focus on how the innovation addresses an existing need tangible to current homeowners. Such needs may be convenience, aesthetics, space efficiency, or safety, to name a few. A "pull"-oriented strategy must be sufficiently flexible and recognize that these needs are likely to change with demographics, tastes, and other dynamic factors.

\subsection{Drive Acceptance by Homebuilders and Remodelers}

There are mutually reinforcing influences between homebuyers and homeowners, on the one hand, and homebuilders and remodelers, on the other, when it comes to facilitating the introduction of new technologies into homes. Informed homebuyers and homeowners who want to incorporate newer technologies in their homes can affect the provision of these new technologies by builders and remodelers by choosing which homes to purchase or which remodeling contractors to hire based on the builders' and remodelers' willingness and ability to provide these features. Builders and remodelers unable or unwilling to accommodate these types of homebuyers or homeowners preferences will lose business, while those that do experience growth. Consumers thus have the potential to have a demand-driven effect on builders and remodelers that rewards better informed, better skilled tradesmen.

This relationship is symbiotic. Just as homebuyers and homeowners can help builders and remodelers increase their awareness of innovations in residential construction, so can homebuilders and remodelers facilitate the introduction of new technologies among homeowners. They can serve as important sources of information to homebuyers and homeowners about the feasibility, the performance, and the cost implications of new housing technologies. Providing those in the building trades with specific cost metrics when newer technologies are more cost effective than existing technologies equips them with a critical and possibly decisive selling point in discussions with homebuyers and homeowners.

\subsection{Define Role for Lenders}

Lenders can, as described in chapter 2, play an important role in encouraging the adoption of newer technologies in owner-occupied housing by homeowners. ${ }^{17}$ Renovation-friendly mortgage lending instruments and flexible home-equity based home improvement loans are two examples of products that affect a homeowner's ability to finance the adoption of newer technologies. Another mortgage product is one that has been likened to a durability mortgage. This durability mortgage includes an escrow

\footnotetext{
${ }^{17}$ The stake of lenders in the durability and technology vintage of the home 's elements. however, is limited. They are not direct stakeholders in these homeowner decisions, although these decisions affect the lender if the borrower defaults on the property.
} 
payment fee for insurance on the home's elements. The fee, and thus the mortgage payment, are lower when housing elements exhibit greater durability and replacements are avoided (Whiddon, Hattis, and Leng, 2004, page 49).

Dissemination of affordability metrics for new housing technologies among lenders would further facilitate the development of mortgage products. This dissemination would best occur through property appraisal. If the appraisal of the home is done to secure a mortgage to purchase the home, a higher appraised value that captures the benefits or future savings from a newer technology housing element may make the prospective buyer more willing to pay more for the home and possibly borrow more to purchase it. The appraisal also documents a higher value of the home. If the appraisal is performed in order to secure a loan against a home's equity, then the higher appraised value will enable the homeowner to take out a larger loan.

\subsection{Provide Guidance to Local Code Officials and Appraisers}

Inclusion of affordability in the International Residential Code is a strong indicator of the interest that model code organizations have in considering the impact that codes and standards have on affordability. However, code enforcement occurs at the local level. Ventre (1980) describes the barriers and vested interests associated with local code officials. One approach to mitigate this resistance is to provide information and reduce uncertainty, such as through the distribution of information about new technologies. This information could include guidance for evaluating novel designs, products, and processes for code compliance. The medium by which this information is disseminated is critical. It could be distributed on CD-ROM, via the Internet, in pamphlet form, or through demonstrations.

Another approach is to offer formalized training programs to these officials, or provide guidance to model code organizations in developing such curricula. Such training could be pursued in conjunction with standardization of certification requirements of code officials among jurisdictions. Instead of focusing on specific technologies that are beginning to appear on the horizon, the training could be based on principles of evaluating newer technologies for code compliance.

In December 2003, the International Code Council, in concert with the National Research Council and PATH, held a conference to address the question of regulatory barriers to the acceptance and adoption of innovations in the construction industry. One outcome of the conference was the conclusion that solutions to address these barriers must focus on "the need to develop centralized, standardized, and binding criteria associated with innovation testing and acceptance" (International Code Council, 2004).

Appraisals affect the receptiveness of homeowners and homebuyers to new housing technologies and are a key source of information to consumers. The National Association of Home Builders Research Center (2001) have identified several aspects of the role of appraisers in the diffusion of new housing technologies and suggested measures to improve the valuation of these new technologies. 


\section{Summary and Recommendations for Further Research}

The United States is currently experiencing historically unprecedented rates of homeownership. This unparalleled base of owner-occupied homes in the United States provides an opportunity to facilitate the adoption of new technologies in owner-occupied homes, the ultimate objective that this report aims to serve by providing guidance on measuring the cost implications of using these new technologies.

\subsection{Summary}

Currently, the durability of the home's systems, materials, and components as well as the operating costs, safety, and maintenance requirements are often not explicitly accounted for in measures of a home's affordability, other than the extent to which a home's age and condition factor into the selling price of a home. This is true despite the effect of these factors on a household's budget. This report identifies ASTM standard-based lifecycle costing as an appropriately broad metric, and offers a roadmap to overcome barriers to acceptance of this defined metric. Table 4-1 is reproduced here to summarize the affordability metrics and the costs that they take into account.

Table 4-1 Summary of Cost Components for Residential Construction Innovations

\begin{tabular}{|c|l|l|l|}
\hline Type & \multicolumn{1}{c}{ Usage } & \multicolumn{1}{c|}{ Affordability Metric } & \multicolumn{1}{c|}{ Included Costs } \\
\hline A & New construction & Difference in first cost & Purchase and installation costs \\
\hline B & Existing housing & Difference in first cost & $\begin{array}{l}\text { Purchase, redesign, and } \\
\text { installation costs }\end{array}$ \\
\hline C & New construction & $\begin{array}{l}\text { Present value of net } \\
\text { savings }\end{array}$ & $\begin{array}{l}\text { First cost for Type A plus } \\
\text { operation, maintenance, and } \\
\text { disposal or resale costs over } \\
\text { relevant time period. }\end{array}$ \\
\hline Existing housing & $\begin{array}{l}\text { Present value of net } \\
\text { savings }\end{array}$ & $\begin{array}{l}\text { First cost for Type B plus } \\
\text { operation, maintenance, } \\
\text { replacement, and disposal or } \\
\text { resale costs over relevant time } \\
\text { period. }\end{array}$ \\
\hline
\end{tabular}

Key barriers to the adoption of new technologies in owner-occupied housing include information gaps and uncertainty among key stakeholder groups, including homeowners and homebuyers; local code enforcement officials: and homebuilders and remodelers. The report proposes ways to reduce those information gaps by equipping homeowners and other decision makers with information about the costs associated with those new technologies. The proposed methodology describes the application and computation of two metrics: first cost and life-cycle cost. A roadmap identifies approaches to broadly disseminate these metrics among the key stakeholder and decision-making groups. Table 5-1, which summarizes these dissemination methods, is reproduced below. 
Table 5-1 Summary of Methods of Dissemination, by Stakeholder

\begin{tabular}{|l|l|}
\hline Stakeholder & Method of Dissemination \\
\hline $\begin{array}{l}\text { Homeowners and } \\
\text { homebuyers }\end{array}$ & $\begin{array}{l}\text { Develop straightforward informational tools; focus on early } \\
\text { adopters. }\end{array}$ \\
\hline $\begin{array}{l}\text { Homebuilders and } \\
\text { remodelers }\end{array}$ & $\begin{array}{l}\text { Symbiotic exchange of information with homeowners and } \\
\text { homebuyers }\end{array}$ \\
\hline Lenders & Higher appraised valuations \\
\hline $\begin{array}{l}\text { Code-setting and } \\
\text { code-enforcement } \\
\text { community }\end{array}$ & $\begin{array}{l}\text { Training, top-down approach by model code organizations, } \\
\text { principles of evaluating new technologies for code compliance. }\end{array}$ \\
\hline Appraisers & $\begin{array}{l}\text { Provide guidelines for valuation of new technologies, with } \\
\text { dissemination in print in appraisal professional publications and } \\
\text { through training at professional society annual meetings. }\end{array}$ \\
\hline
\end{tabular}

\subsection{Recommendations for Future Research}

This research on the affordability of new technology in owner-occupied housing in the United States can be extended in several ways.

An assumption implicit in the discussion of new residential construction technologies is the constancy of their costs over time. Costs may, however, decrease over the long term as the new technology matures and penetrates its markets. With expanding markets, manufacturers may experience economies of scale in the production process, leading to declines in unit production costs. Manufacturers may also gain experience in the production process that allows them to operate more efficiently. These cost savings may be passed on to consumers. Competition from other manufacturers can also push prices down, and a broader base of skilled tradesmen adept at installing the new technology may also reduce labor installation prices. Additional research can investigate the implications for the first-cost affordability of new technologies if we weaken the assumption that prices stay constant.

Life-cycle cost analysis described in this report addresses uncertainty (such as that due to natural hazards) by assuming homeowners are risk neutral. Future research can extend this analysis to adapt to the more realistic case of risk-averse decision makers. Rather than focusing on cost as the metric, for example, an approach based on contingent valuation $^{18}$ may better capture a homeowner's risk aversion. Another extension of the affordability metric could incorporate methods of factoring in qualitative aspects of homes based on user-defined weights, such as through multi-attribute decision analysis.

\footnotetext{
${ }^{18}$ Contingent valuation is the use of data from survey questionnaires to estimate the willingness of respondents to pay for public projects, programs, or risk reduction. A typical question may be framed, "Would you be willing to pay $X$ dollars to receive benefit $Y$ ?", or "How much would you be willing to pay in dollars to receive benefit $Y$ ?" For further discussion of contingent valuation, see Bishop and Heberlein (1990) and Portney (1994).
} 
References

American Heritage Dictionary of the English Language, Fourth Edition, 2000.

ASTM International. 1998. "Software to Support ASTM E 1765: Standard Practice for Applying Analytical Hierarchy Process (AHP) to Multiattribute Decision Analysis of Investments Related to Buildings and Building Systems." West Conshohocken, Pennsylvania: ASTM International.

ASTM International. 2002a. "Standard Practice for Applying Analytical Hierarchy Process (AHP) to Multiattribute Decision Analysis of Investments Related to Buildings and Building Systems," E 1765, Annual Book of ASTM Standards: 2002. Vol. 04.12. West Conshohocken, Pennsylvania: ASTM International.

ASTM International. 2002b. "Standard Practice for Measuring Life-Cycle Costs of Buildings and Building Systems," E 917, Ammual Book of ASTM Standards: 2002. Vol. 04.11. West Conshohocken, Pennsylvania: ASTM International.

Aversa, Jeannine. 2005. "Greenspan Warns on Fannie, Freddie Again." The Associated Press. May 5, 2005.

Bishop, Richard C. and Thomas A. Heberlein. 1990. "The Contingent Valuation Method," in Johnson, Rebecca L. and Gary V. Johnson, eds. Economic Valuation of Natural Resources: Issues, Theory, and Applications. Social Behavior and Natural Resources Series. Boulder and Oxford: Westview Press, pp. 81-104.

Building Technology Incorporated. 2005. Overcoming Barriers to Innovation in the Home Building Industry. Volumes 1 and 2. April 2005. Washington, D.C.: Department of Housing and Urban Development.

Burby, Raymond J., Peter J. May, Emil E. Malizia, and Joyce Levine. 2000. "Code Enforcement Burdens and Central City Decline." Journal of the American Planning Association. Vol. 66, Spring 2000, pp. 143-161.

Chan, Thomas Sai-fan. 1999. "Residential Construction and Credit Market Imperfection." Journal of Real Estate Finance and Econonics. Vol. 18, 1999, pp. 125-139.

Chapman, Robert E. 2000. Benefits and Costs of Research: A Case Study of Construction Systems Integration and Automation Technologies in Industrial Facilities. NISTIR 6501. Gaithersburg, Maryland: National Institute of Standards and Technology.

Chapman, Robert E. and Christine A. Izzo. 2002. Baseline Measures for Improving Housing Durability. NISTIR 6870. Gaithersburg, Maryland: National Institute of Standards and Technology. 
Diaz-Serrano, Luis. 2004. "On the Negative Relationship between Labor Income Uncertainty and Homeownership: Risk Aversion vs. Credit Constraints." IZA Discussion Paper. No. 1208, July 2004.

Felsenthal, Mark. 2005. "Greenspan sees GSE Portfolio Risk for Swaps Market." Reuters. May 5, 2005.

Fuller, Sieglinde K. and Stephen R. Petersen. 1996. Life-Cycle Costing Manual for the Federal Energy Management Program. NIST Handbook 135. Gaithersburg, Maryland: National Institute of Standards and Technology.

Fullerton, Thomas M., Jr., Juan A. Luevano, and Carol T. West. 2000. "Accuracy of Regional Single-Family Housing Start Forecasts." Journal of Housing Research. Vol. 11, Iss. 1, 2000, pp. 109-120.

Glaeser, Edward L. and Joseph Gyourko. 2002. "The Impact of Zoning on Housing Affordability." Harvard Institute of Economic Research Discussion Paper. No, 1948, March 2002.

Glaeser, Edward L. and Joseph Gyourko. 2003. "The Impact of Building Restrictions on Housing Affordability." Federal Reserve Board of New York Economic Policy Review. June 2003.

Glaeser, Edward L. and Joseph Gyourko. 2005. "Why Have Housing Prices Gone Up?" NBER Working Paper. No. 11129, February 2005.

Greenspan, Alan. 2005. Risk Transfer and Financial Stability: Remarks by Chairman Alan Greenspan to the Federal Reserve Bank of Chicago's Forty-first Annual Conference on Bank Structure. Chicago, Illinois. May 5, 2005.

Hendershott, Patric H. and John C. Weicher. 2002. "Forecasting Housing Markets: Lessons Learned." Real Estate Economics. Vol. 30. Iss. 1, Spring 2002, pp. 1-11.

International Code Council. 2004. "PATH Roundtable on Codes: Removing Building Regulatory Barriers," January 2004.

International Conference of Building Officials (ICBO). 2000. International Residential Code for One and Two-Family Dwellings. Whittier, CA: ICBO.

Kunreuther, Howard, Robert Meyer, and Christophe van den Bulte. 2004. Risk Analysis for Extreme Events: Economic Incentives for Reducing Future Losses. NIST-GCR 04-871. Gaithersburg, Maryland: National Institute of Standards and Technology. 
Levine, Ned. 1999. "The Effects of Local Growth Controls on Regional Housing Production and Population Redistribution in California." Urban Studies. Vol. 36, No. 12, 1999, pp. 2047-2068.

Mankiw, N. Gregory and David N. Weil. 1989. "The Baby Boom, the Baby Bust, and the Housing Market." Regional Science and Urban Economics. Vol. 19, 1989, pp. $235-258$.

Mansfield, Edwin. 1995. Innovation, Technology and the Economy: Selected Essays of Edwin Mansfield. 2 vols. Economists of the Twentieth Century series. Aldershot, United Kingdom: Elgar.

Max, Sarah. 2005. "Going out on a limb." CNNmoney.com. April 23, 2005, http://money.cnn.com/2005/04/22/real_estate/financing/lendingrisk/index.htm.

Mayer, Christopher J. and C. Tsuriel Somerville. 2000. "Residential Construction: Using the Urban Growth Model to Estimate Housing Supply." Journal of Urban Economics. Vol. 48, 2000, pp. 85-109.

Meese, Richard and Nancy Wallace. 1991. "Nonparametric Estimation of Dynamic Hedonic Price Models and the Construction of Residential Housing Price Indices." AREUEA Journal. Vol. 19, No. 3, 1991, pp. 308-332.

Meese, Richard and Nancy Wallace. 1997. "The Construction of Residential Housing Price Indices: A Comparison of Repeat-Sales, Hedonic-Regression, and Hybrid Approaches." Journal of Real Estate Finance and Economics. No. 14, 1997, pp. 5173.

Montgomery County Department of Housing and Community Affairs. 2001. Technical Supplement to the Housing Policy. Updated July 2001. Website: http://www.montgomerycountymd.gov/Content/DHCA/housing/housing_P/policy/pol icy_new.asp (last accessed on May 20, 2005).

National Association of Home Builders (NAHB) Research Center. 2001. "Housing Innovation and the Appraisal Process." Building Industry Roundtable. December 18, 2001 .

National Association of Home Builders (NAHB) Research Center. 2003. "PATH Technology Inventory Review," September 15, 2003.

Office of the Comptroller of the Currency, Board of Governors of the Federal Reserve System, Federal Deposit Insurance Corporation, Office of Thrift Supervision, and National Credit Union Administration. 2005. "Credit Risk Management Guidance for Home Equity Lending," May 16, 2005. 
Portney, Paul R.. 1994. "The Contingent Valuation Debate: Why Economists Should Care." Journal of Economic Perspectives. Vol. 8, No 4, pp 3-17.

Pryce, Gwilym. 1999. "Construction Elasticities and Land Availability: A Two-state Least-squares Model of Housing Supply Using the Variable Elasticity Approach." Urban Studies. Vol. 36, No. 13, 1999, pp. 2283-2304.

Rogers, Everett M. 1995. Diffusion of Innovations. New York City, New York: The Free Press.

Simmons, Kevin M., Jamie Brown Kruse, and Douglas A. Smith. 2002. "Valuing Mitigation: Real Estate Market Response to Hurricane Loss Reduction Measures." Southern Economic Journal. Vol. 68, Iss. 3, January 2002, pp. 660-671.

Sirmans, G. Stacy and David A. Macpherson. 2003a. "The Composition of Hedonic Pricing Models: A Review of the Literature," National Association of Realtors National Center for Real Estate Research, December 2003.

Sirmans, G. Stacy and David A. Macpherson. 2003b. "The Value of Housing Characteristics," National Association of Realtors National Center for Real Estate Research, December 2003.

Slaughter, E. Sarah. 1998. "Models of Construction Innovation." Journal of Construction Engineering and Management. Vol. 124, Iss. 3, May/June 1998, pp. 226-231.

Snow, John. 2005. Testimony of Secretary John W. Snow Before the U.S. Senate Committee on Banking, Housing and Urban Affairs: Proposals for Housing GSE Reform. April 7, 2005.

Somerville, Glenn. 2005. “U.S.'s Snow - Tougher Rules Won’t Hurt GSE Mission." Reuters. April 26, 2006.

Spiegel, Matthew. 2001. "Housing Return and Construction Cycles." Real Estate Economics. Vol. 29, No. 4, Winter 2001, pp. 521-551.

Stoneman, Paul. 1983. The Economic Analysis of Technological Change. New York: Oxford University Press.

U.S. Census Bureau. 1999. American Housing Survey for the United States: 1997. Current Housing Reports, Series H150/97. Washington, D.C.: U.S. Government Printing Office.

U.S. Census Bureau. 2002. American Housing Survey for the United States: 2001. Current Housing Reports, Series H150/01. Washington, D.C.: U.S. Government Printing Office. 
U.S. Census Bureau. 2005. Current Population Survey/Housing Vacancy Survey.

U.S. Department of Housing and Urban Development (HUD). 2003. HUD Strategic Plan: FY 2003-FY 2008. Washington, D.C.: HUD.

U.S. Senate. 2005. Community Development Homeownership Tax Credit Act. S. 859. April 20, 2005, $109^{\text {th }}$ Congress, $1^{\text {st }}$ Session.

Ventre, Francis T. 1980. "On the Blackness of Kettles: Inter-Industry Comparisons in Rates of Technological Innovation." Policy Sciences. Vol. 11, No. 3, February 1980, pp. 309-328.

Vigdor, Jacob. 2004. "Liquidity Constraints and Housing Prices: Theory and Evidence from the VA Mortgage," NBER Working Paper, No. 10611, June 2004.

Whiddon, William I., David B. Hattis, and Chi J. Leng. 2004. Measuring and Assessing the Consequences of Technology and Innovations for Affordability of Housing: Proceedings of the NIST-PATH Workshop. NIST Internal Report 7064. Gaithersburg, Maryland: National Institute of Standards and Technology. February 2004. 


\title{
Affordability Guidelines for Owner-Occupied Housing
}

\author{
A White Paper by \\ Robert E. Chapman and Harold E. Marshall \\ Office of Applied Economics (OAE) \\ Building and Fire Research Laboratory (BFRL) \\ National Institute of Standards and Technology (NIST) \\ Gaithersburg, MD 20899
}

\section{Introduction}

Affordability, as it relates to housing, has been added to the International Residential Code. ${ }^{19}$ There is no standard, uniform, or accepted definition of affordability, however, that code officials can use to define and measure affordability. Without a set of guidelines (i.e., protocol) for measuring affordability, manufacturers, code officials, and consumers will not have a clear methodology for evaluating the affordability of alternative or new housing technologies in owner-occupied housing. The NIST project "Affordability Guidelines for Owner-Occupied Housing" will develop that protocol in collaboration with building community stakeholders. The guidelines will show how to measure and evaluate the affordability of alternative residential building technologies when compared with a conventionally used technology satisfying the same function or code requirement. The guidelines will accommodate multiple measurement methodologies. For example, one such methodology is life-cycle costing as described in ASTM standard practice E $917 .{ }^{20}$ The consensus affordability guidelines resulting from this joint effort will result in a more rapid introduction of new, more cost-effective technologies in housing, thereby supporting HUD's Strategic Goal 1: Increasing the Availability of Decent, Safe, and Affordable Housing in American Communities. ${ }^{21}$

\section{Project Description}

There are four steps in the development of the affordability guidelines. The first is the completion of this white paper. It will be used as a background piece by participant stakeholders in an affordability workshop to identify (1) what affordability means to them and (2) what sorts of measurement guidelines would help them. The second step is to convene the workshop to provide a framework for discussing key affordability-related issues. Discussion topics will be developed and refined for use by participants of the affordability workshop to focus their discussion and to get their views on affordability-

\footnotetext{
19 International Conference of Building Officials (ICBO). 2000. International Residential Code for One and Two-Family Dwellings. Whittier, CA: ICBO.

${ }^{20}$ American Society for Testing and Materials (ASTM). 2001. Antulual Booh of ASTM Standards 2001: Volune 04.11 Building Construction. West Conshohocken, PA: ASTM.

21 U.S. Department of Housing and Urban Development (HUD). 2001. Fiscal Year 2002 Aumual Performance Plan. Washington, DC: HUD.
} 
related issues. The third step is to develop a consensus roadmap based on the workshop outputs. NIST will explore ways in which reliance on a carefully selected set of standard practices and input from the stakeholder groups can be used to produce a consensus roadmap for developing a set of affordability guidelines. The consensus roadmap will include plans for awareness building and information dissemination. It is believed that this approach will facilitate the deployment of a set of affordability guidelines that can be supported by each of the key stakeholder groups. The fourth step is the production of the affordability guidelines.

\section{Customers and Stakeholders}

Customers are the intended users of the affordability guidelines. A manufacturer who wants to advertise the relative affordability of a new product, for example, could measure that affordability with the guidelines. A consumer who wishes to compare the affordability of a new roofing shingle to conventional shingles is also a customer. These customers are at the same time the stakeholders. Having or not having affordability guidelines makes a difference in their evaluation of housing products. Thus they have a stake in what those guidelines say.

Six key customer/stakeholder groups are (1) homeowners, or their representatives, who wish to select a particular material, product, or system; (2) home builders, remodelers, developers, and their subcontractors and suppliers; (3) innovators, manufacturers, distributors, and retailers who wish to verify that their material, product, or system meets affordability; (4) code officials and evaluation services who wish to judge if the proposed material, product, or system meets code requirements; (5) real estate, financial, and insurance institutions and their agents; and (6) government programs concerned with housing-related issues (e.g., HUD, FEMA, DOE, and DOD).

Each of these groups must be represented at the workshop because housing industry stakeholders are affected in different ways by affordability-related issues. Focus groups in the workshop will consider alternative measures of affordability and comment on how each of those measures would or would not help them when making choices among housing technologies. Special emphasis will be placed on documenting how each stakeholder group looks at affordability.

\section{Key Concepts}

Selected speakers will introduce topics for discussion. They will give some background information so that all participants will understand the key concepts. Specific discussion topics will include, but are not limited to, the following: (1) technology in owneroccupied housing; (2) first costs of a technology; (3) life-cycle costs of a technology; and (4) economic incentives as they impact adoption of housing technologies. Breakout sessions will follow the presentations to allow full participation of the stakeholder representatives. The workshop organizers will facilitate the discussion and keep notes of the proceedings. 
Technologies in housing, for our purposes, are defined as ways of designing, constructing, producing, or of combining materials. New technologies in housing are often slow to be adopted because of uncertainties about what they will cost stakeholders, both in the short and long run. Yet new technologies can be more cost effective than traditional technologies. Having a set of guidelines for measuring the cost effectiveness of new technologies will encourage their consideration and adoption.

First costs are those incurred at the beginning of a project. The first costs of windows, for example, when examined from the perspective of the homeowner, is what the windows cost to purchase and install. If we compare a traditional window system to an new technology on the basis of first costs, we would say the new technology is affordable on a first cost basis if its cost is less than or equal to that of the conventional technology used to satisfy the same function or code requirement.

Life-cycle costs are all costs associated with a given technology. They include first costs; operations, maintenance, and repair costs over a specified life cycle (e.g., the typical holding period for owner-occupied housing); and any other costs associated with the technology over time. These life-cycle costs could be expressed as monthly mortgage costs (i.e., principal, interest, taxes, and insurance) or monthly holding costs (i.e., mortgage costs plus amortized operations, maintenance, energy, and repair and replacement costs). Thus the life-cycle costs of a new-technology window system would take into account, in addition to the purchase and installation costs (first costs), all costs of repairs, replacement, and even energy savings if the new system resulted in better thermal performance than the conventional system to which it was being compared.

Incentives are important in evaluating affordability because they affect the bottom line of how much building technologies ultimately cost a stakeholder. Cost sharing, tax credits or deductions, and grants to stakeholders will make new housing technologies more affordable when compared with technologies not favored with incentives. If a state government, for example, were to cost share the first cost of residential solar hot water heaters, the life-cycle costs of solar hot water (taking into account reduced energy bills for water heating) could become affordable (i.e., cost competitive) with conventional water heating systems. Cost sharing, tax deductions or credits, and grants to stakeholders, whether taken singly or in combination, all affect stakeholder affordability.

\section{Expected Outcome}

The expected outcome is a report from the workshop contractor that summarizes the needs, by stakeholder/customer, of measures for affordability in relation to housing technologies. The report will form the blueprint for making a roadmap of what needs to be done in developing a set of affordability guidelines for owner-occupied housing. By following this blueprint, stakeholders will ultimately have a standardized, accepted definition of affordability that meets their needs and will help them make more costeffective choices in owner-occupied housing. 


\section{Appendix B - History, Trends, and Data}

This appendix describes key characteristics of owner-occupied housing in the United States. These characteristics - the volume of new construction, the frequency at which existing homes change hands, and owners' assessments of home values - affect the penetration of residential construction innovations. A change in ownership of homes is an opportunity for the introduction of new materials and components into the unit, as new homeowners rehabilitate or replace systems close to the end of their service life. New construction also provides an opportunity for builders to incorporate newer materials and methods into the home. The recent volume of residential real estate transactions contributes to the introduction of more updated technologies into the housing stock. Similarly, homeowners' assessments of their homes' values may reflect their expectations of recouping at resale the costs of adopting innovations. These selfassessments also affect homeowners' willingness to tap into their homes' equity to finance the adoption of innovations.

\section{B.1 Current and Historical Rates of Homeownership}

During the first quarter of 2005, the United States experienced a 69.1 percent rate of home ownership, the highest rate in over 40 years. After periods of flat or fluctuating rates of homeownership from the late 1960s through the mid-1990s, the rate of homeownership began to trend upward beginning in 1994 (see Figure B-1). This unparalleled rate of homeownership suggests that housing had never been more affordable, and that the opportunity for affordability metrics to promote penetration of residential construction innovations into owner-occupied housing has never been more promising.

Homeownership rates varied across the United States. The region with the highest rate of homeownership is the Midwest, with 73.1 percent, followed by the South, at 71.1 percent, and the Northeast, at 65.4 percent. The West is associated with the lowest rate of homeownership, at 64.9 percent (U.S. Census Bureau, 2005). The regional variation in homeownership indicates similar variation in opportunity for the introduction of new technologies into owner-occupied homes. This variation is important since some innovations are applicable to some regions and not others, for example on the basis of climate.

In the first quarter of 2005, total housing inventory in the United States was 123.3 million units, 107.8 million of which were occupied. ${ }^{22}$ Of these occupied homes, 69.1 percent were owner occupied. Recent estimates of existing housing stock vacant and for sale are modest: 1.1 percent, or 1.4 million units, in 2005 , up slightly compared to first quarter 2004 figures of 1.0 percent, or 1.3 million units (U.S. Census Bureau, 2005).

\footnotetext{
${ }^{22}$ The 15.3 million estimated housing units that were vacant in 2003 include seasonal and year-round vacancies. Year-round vacancies include units for rent. units for sale only. units rented or sold but awaiting occupancy, and units held off the market. Units are held off the market for occasional use, for temporary occupation by persons with another residence, or for other reasons.
} 
Figure B-1

Homeownership in the United States

1960-2004

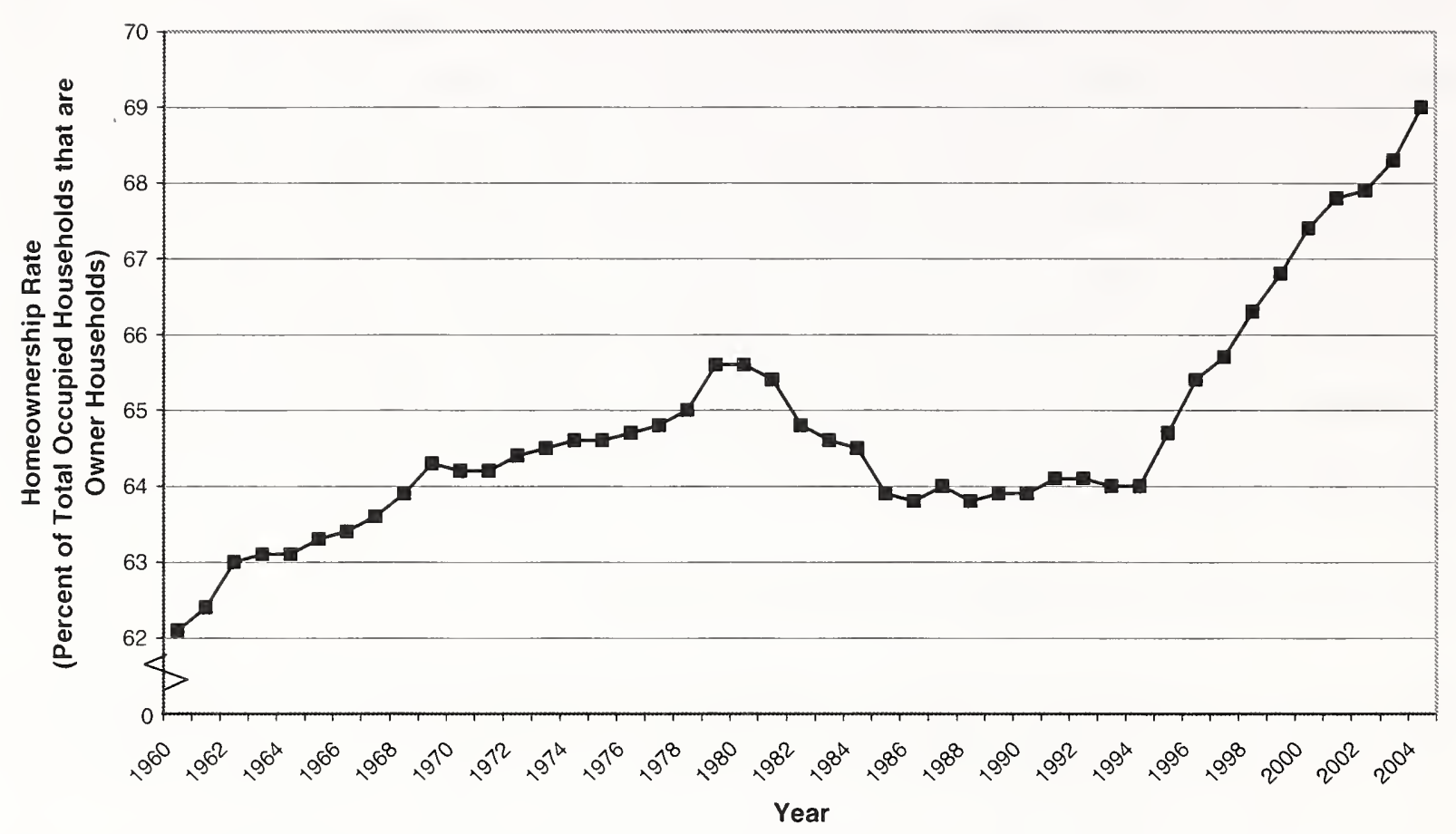

The recent increase in the rate of homeownership is associated with a high level of turnover of homeownership. In 2001, 9.6 million households living in owner-occupied housing, or 13.2 percent, were on the move during the previous year. One consequence of the high turnover is that that many units have not been occupied by current owners for very long. As of 2001, 41.6 percent of all owner-occupied units had been occupied by current owners beginning no earlier than 1995. For an additional 27.6 percent of units, householders moved into the unit between 1985 and 1994. In 2001, the median year that a homeowner moved into the home was 1992. This figure implies median tenure in owner-occupied homes of 9 years (U.S. Census Bureau, 1999 and U.S. Census Bureau, $\left.2002^{23}\right)$.

\section{B.2 Price Trends}

In addition to rates of homeownership in the United States, price trends also factor into the decision by homeowners whether to adopt new technologies in their homes. In areas where home sale prices are stable or increasing, homeowners may be more willing to invest in their home through upgrades and retrofits if they believe that these costs will be recouped when the home is sold. In addition, stable or increasing home values facilitate the financing of home improvements through the availability of home equity-based loan instruments.

\footnotetext{
${ }^{23}$ For background about the American Housing Survey, see Chapman and Izzo (2002, pp. 21-22).
} 
There are several approaches to evaluate trends in housing prices nationwide. ${ }^{24}$ Among them are valuations and purchase prices. ${ }^{25}$ According to both of these measures, housing prices have increased.

One approach to looking at home prices is to compare valuations. In 2001, the median value of owner-occupied homes in the United States was $\$ 123,886 .^{26}$ For homeowners who moved during the year before the survey, the median value in 2001 was 7.1 percent higher, at $\$ 132,722$. For homes constructed during the four years prior to the survey, the median value was even higher: $\$ 164,818$, or 33 percent higher than the median for all owner-occupied homes.

Another approach is to examine purchase prices. The sale prices of homes have grown in the United States. For new, one-family homes sold in the United States (including the value of the lot), prices increased 31.9 percent between 1996 and 2003. ${ }^{27}$ For all homes purchased in all years, the median purchase price reported by the survey respondents in 2001 was $\$ 68,899 .^{28}$ For homeowners who moved during the year prior to the survey, their median purchase price was $\$ 123,465$. For homeowners living in homes built in the four years prior to the survey, the median price paid was $\$ 149,013$.

For some housing components and materials, there is evidence of a tradeoff between the purchase price of a home, or first cost, and durability. The higher prices of newer construction and more recent home purchases may be attributable to use of more durable construction methods, materials, and components. Hedonic models of housing prices examine some effects of housing characteristics on housing prices (see, for example, Meese and Wallace (1991), Gençay and Yang (1996), Meese and Wallace (1997), Sirmans and Macpherson (2003a), and Sirmans and Macpherson (2003b)). Sirmans and Macpherson (2003b) in particular present a hedonic model of home prices based on about 28,000 recent transactions in Philadelphia's residential real estate market. This model estimates home sales price responses to different housing characteristics. The authors find, for example, that homes clad with vinyl siding, which lasts 15 years, are priced at a 3.5 percent discount compared to homes with brick exteriors, which last 100 years. To take another example, homes built with slate roofs, which last 45 years, are priced at a 9.9 percent premium over homes with asphalt shingle roofs, which last 20 years. Nevertheless, housing prices are also sensitive to macroeconomic factors, such as new housing construction, demographic trends, mortgage and other financial institutions, local

\footnotetext{
${ }^{24}$ Housing cost. home valuation, and purchase price data are from the results of the American Housing Survey of the United States. 2001.

${ }^{25}$ Although residential construction costs are one factor affecting housing prices. they are not discussed here. For a thorough discussion of these and other household residential expenditures based on the Census of the Construction Industry, see Chapman and Izzo (2002. pp. 17-21).

${ }^{26}$ Value is the survey respondent's estimate of how much the property (house and lot) would sell for if it were for sale. In the case of the American Community Survey (ACS). another survey that includes such data, however, it has been shown that homeowners overstate self-reported home values by six to eight percent.

${ }^{27}$ U.S. Bureau of the Census new residential sales data.

${ }^{28}$ The purchase price refers to the price of the house or apartment and lot at the time the property was purchased. Closing costs are excluded from the purchase price. and for mobile homes. the value of land is excluded.
} 
employment and interest rates (for example, see Mankiw and Weil (1989) and Vigdor (2004)).

Trends in housing prices vary from region to region. In some parts of the country, growth has been at double-digit rates or more over the last five years. In other areas, prices have been stagnant or even declining. In the Oakland zip code of 94621 , for example, the price of homes subject to repeat sales grew 159.8 percent, the highest in the nation, over the five years between the fourth quarters of 1998 and 2003. Among the ten largest metropolitan areas, the metropolitan statistical area (MSA) with the highest price increase over the same five-year period is Los Angeles-Riverside-Orange County, at 90.0 percent, based on repeat sales data. ${ }^{29}$ The New York-Northern New Jersey-Long Island MSA ranks second, with prices increasing 80.7 percent over the same period, and Boston-Worcester-Lawrence is third, at 79.2 percent. In the tenth and last MSA on the list, Detroit-Ann Arbor-Flint, home prices increased 31.3 percent over the same period.

According to National Association of Realtors (NAR) data released on February 12, 2004, the housing markets with the fastest median price growth during the one year between the last quarter of 2002 and the last quarter of 2003 were in California and Florida: Riverside/San Bernardino, CA (28.9 percent), Sarasota, FL (26.1 percent), Los Angeles area (24.5 percent), Miami/Hialeah, FL (22.9 percent), Anaheim/Santa Ana, CA (21.2 percent), and San Diego (20.4 percent). Of the 127 markets tracked by the NAR, 22 markets had drops in median prices. These areas were predominantly, but not exclusively, located in the South and Midwest. The areas with the largest declines were Jackson, MS ( -5.4 percent), Akron, $\mathrm{OH}$ ( -5.3 percent), Toledo, $\mathrm{OH}(-4.7$ percent $)$, Montgomery, AL (-4.4 percent), Birmingham, AL (-3.7 percent), and Ft. Wayne, IN (-3.0 percent).

\section{B.3 Housing Supply: Existing Stock and New' Construction Flows}

Opportunities for the introduction of new technologies in owner-occupied housing exist for both existing housing and for new construction. However, the way these innovations are introduced and adopted vary between the two. Some innovations, such as radiant barriers, ${ }^{30}$ are more easily applied to new construction, while others, such as aerosol duct sealing, ${ }^{31}$ are intended to address issues facing existing homes. For existing homes, the year of construction is also a factor, since owners of older homes that had not previously been renovated have more motivation to upgrade through the use of newer materials, systems, and technologies. This section quantifies the stock of housing in the United States and the rate at which this stock grows through new construction to give a sense of the scale relevant for these innovations.

\footnotetext{
29 Source: money.cnn.com, citing Fiserv Case Shiller Weiss estimates. Data refer to changes in median prices over the five years between fourth quarter of 1998 and fourth quarter of 2003. Five-year price changes are based on repeat sales data for a sample of homes in each zip code.

${ }^{30}$ For more information about radiant barriers, please visit: http://www.toolbase.org/tertiaryT.asp?TrackID=\&CategoryID=1402\&DocumentID=2141.

${ }^{31}$ For more information about aerosol duct sealing, please visit: http://www.toolbase.org/tertiaryT.asp?TrackID=\&CategoryID=1402\&DocumentID=2083.
} 
In 2001, there were 72.3 million owner-occupied housing units in the United States, including single-unit detached homes, single-unit attached homes (such as townhouses), multi-unit structures, and manufactured/mobile homes. Of this total, 4.7 million were built after 1997. The median year of construction for all housing units was 1970, although 16.2 million units, or 22.4 percent, were built before $1950 .^{32} 59.2$ million housing units, or 82.0 percent, were detached, single family homes, 3.7 million were attached, single family homes, 3.3 million were multi-family structures, and 6 million were manufactured or mobile homes. 25.7 million, or 38.7 percent, of housing units (excluding manufactured and mobile homes) were single story. The median home had 3 bedrooms and 2 or more bathrooms. The median size of the 65.2 million single detached and manufactured/mobile homes was $166.5 \mathrm{~m}^{2}\left(1,798 \mathrm{ft}^{2}\right)$. The median lot size of the 67.4 million single-unit structures was slightly less than $1618.8 \mathrm{~m}^{2}(0.4$ acres $)$. Of the 72.3 million total owner-occupied units, about 3 million units had moderate to severe physical problems. $^{33}$

The stock of residential housing in the United States is comprised of two components: existing homes and new construction. Some estimates put the rate of increase of the stock of residential housing at 2 percent to 3 percent annually. The 2001 American Housing Survey for the United States suggests that the rate of increase of the owneroccupied housing stock over the previous four years was approximately 6.5 percent. ${ }^{34}$ Consequently, although penetration of new construction materials or methods through newly constructed housing may be slow, it is a key way that new or more current technologies penetrate the marketplace.

The functionality of existing homes depends on their age, the materials and methods used during construction and renovation, maintenance history, and rehabilitation. Construction of new housing is shaped by the structure of the home-building industry, local zoning and land use regulations, and broader macroeconomic and demographic factors affecting demand for housing (Pryce (1999), Chan (1999), Fullerton, Luevano, and West (2000), Mayer and Somerville (2000), Spiegel (2001), and Henderschott and Weicher (2002)).

As in the case of sale prices, there is a great deal of variation in housing markets from region to region. In Phoenix, for example, 30 percent of the housing inventory was constructed in the last five years. Differences in the volume of turnover of existing units and construction of new housing units across the United States suggests that there may be regional variations in the introduction of new technology and penetration of existing technology.

\footnotetext{
32 Baer (1990) describes several difficulties in estimating the age of the nation s housing stock, such as inadequate local data or unreliable data (i.e., conjecture) from surveys of occupants or owners.

${ }^{33}$ Criteria for determining severe or moderate physical problems were based on upkeep and conditions or functionality of a unit's plumbing, heating. electric. and hallways. For moderate physical problems. the condition of the kitchen was an additional factor. For detailed descriptions of these criteria. see Appendix A of the American Housing Survey for the United States: 2001 (U.S. Census Bureau. October 2002).

${ }^{3+}$ This estimate is based on 4.7 million owner-occupied units constructed in the four years prior to the survey date.
} 
Chapman and Izzo describe baseline measures of service life for building elements in chapter 4 of Chapman and Izzo (2002). They examine various data sources, including ASTM International, the National Association of Home Builders (NAHB), Whitestone Research, the American Society of Heating, Refrigerating, and Air-Conditioning Engineers (ASHRAE), and the California Energy Commission. Chapman and Izzo present the mean expected service lives for several housing elements from each source. According to the NAHB, the average anticipated service life for a cement foundation, for example, is 50 years, in contrast to the 100-year expected service life of a concrete block foundation. Chapman and Izzo compile data from the various sources into one table, Table 4-4 of the 2002 report, describing service life for several sub-elements of each of the major building elements: plumbing, heating, ventilation and air-conditioning (HVAC), siding, roofing, windows, and doors. 


\section{Appendix C-PATH ToolBase: Technology Inventory}

Advanced Framing Techniques: Optimum Value Engineering (OVE)

Aerobic Wastewater Treatment Units

Aerosol Duct Sealing

Air Admittance Vents

Aluminum-Plastic Composite Water Piping

Autoclaved Aerated Concrete

Bamboo Flooring

Basement Escape System

Blower Door

Cellular PVC Lumber

Cement Substitutes

Central Air Purification/Ventilation/Dehumidification Systems

Cob and Adobe Construction

Combination Steel/Wood Framing -

Combination Ventilation and Drip Edge System

Composite Window Frames

Concrete Admixtures

Concrete Aggregate Substitutes

Concrete Footing and Pier Forms

Concrete Formed Homes

Constructed Wetlands for Wastewater Treatment

Corrugated Stainless Steel Tubing (CSST) for Gas Distribution

Crawl Space Foundation Systems

Crystalline Concrete Waterproofing

Decorative Concrete Floor Finishes

Desiccant Cooling

Drainwater Heat Recovery

Drip Irrigation Leach Field

Drywall Clips and Stops

Drywall Finishing Accessories

Duct Leakage Testing

Ductless (Mini-Split) Heat Pumps

EIFS-Drainable Systems

Electric Moisture Meters

Electric Radiant Ceiling Panel

Electric Vehicle ReCharging Station

Electrical Raceways

Electrochromic Windows

Emergency Power Backup Systems

Energy-Efficient Interior Storm Windows

Engineered Wood Wall Framing

Evaporative Coolers

Fastenerless Steel Framing-Clinching

Fiber-Cement Siding 
Fiberglass Reinforced Plastic Exterior Decks

Fibrous Concrete Reinforcement

Flexible Framing Anchor Straps

Flexible Framing Track

Fly Ash Concrete

Flywheel Energy Storage

Foundation Drainage Panels

Foundation Flood Vents

Frost Protected Shallow Foundations

Fuel Cell Electrical Generation

Full Spectrum Fluorescent Lamps

Geothermal Heat Pumps

Gravel-Less Pipe Leach Fields

Greywater Reuse

Grid-Marked Sheathing

Guide Marked Gypsum

Heat Pump Water Heaters

Heat/Energy Recovery Ventilators (HRV/ERV)

High Efficiency Air Conditioners without HCFC

High Wind- and Impact-Resistant Asphalt Roofing Shingles

High-Efficiency Refrigerators

Horizontal Axis (Front-Loading) Clothes Washers

Horizontal Axis Washer-Dryer Combination Unit

Hot Water Recirculation System

Humidity-Sensing Control Device

HVAC "Smart" Zoning Controls

HVAC Equipment and Duct Installation within Conditioned Space

HVAC Sizing Practice

Hybrid Modular/Panelized Housing

Hydronic Radiant Cooling

ICF Walls - Wood Fiber Composite Forms

Impact Resistant Glazing

Information-Age Wiring for Home Automation Systems

In-Line Fans

Insulated Headers

Insulating Concrete Forms

Insulation Alternatives: Blown or Foamed Through a Membrane

Insulation Alternatives: Non-Fiberglass Batts

Insulation Alternatives: Sprayed Fiber Insulation

Insulation Alternatives: Sprayed Foam Insulation

Insulative Vinyl Siding

Kitchen Recycling Center

Laminar Flow Fixtures

Latex Foam Sealant

Low Impact Development (LID) Practices for Stormwater Management

Low- or No-VOC Paints 
Low-E Glass and Spectrally Selective Glazing

Low-Flow Plumbing Fixtures

Manufactured Housing Disaster-Resistant Pier Systems

Manufactured Housing Ground Anchor Systems

Mini-Duct Air Distribution System

Modular Air Handler Hot Water Coil

Modular Block Retaining Wall Systems

Modular Multiple Dwellings

Modulating Furnace

Mortarless Brick Veneer

Natural Gas Refueling Station

New Generation OSB Sub-flooring

On-Site House Factory

On-Site Sewage Disposal Systems

Panelized Wall and Roof Systems

Passive Solar Ventilation Air Pre-heater

Permeable Pavement

Phase Change Materials

Photovoltaic (PV) Roofing

Plastic Chamber Leach Fields

Plastic Composite Nails

Plastic Composite Siding

Plastic Exterior Trim

Plastic Plumbing Manifold

Pre-Cast Concrete Foundation Panels

Pre-Cast Concrete Passive Solar Home

Prefabricated Exterior Stairs

Prefabricated Storm Shelter

Pressurized Leach Field Dosing

Programmable Thermostats

Pumice-Crete

Radiant Barriers

Radiant Floor Heating - Dry System Hydronic

Rain Screen Exterior Walls

Rainwater Harvesting

Rammed Earth Construction

Ray-Core Panels

Recirculating Sand Filters

Recycled Content Carpet

Recycled Wood Flooring

Recycled Wood/Plastic Composite Lumber

Reduced Thickness Wall Studs

Residential Light Gauge Steel

Reverse Cycle Chiller 
Self-Contained Heat Pump/Air Handler

Shared Wastewater Treatment Systems

Shear Wall Panels

SIP Modular Housing

Smart Vapor Retarders

Solar Cooling

Solar Water Heaters

Split-Face Concrete Block

Spray-Applied Concrete Walls

Steel L-Headers

Steel-Framed Modular Housing

Straw-Bale Construction

Straw-Based Building Products

Strawboard Panels

Structural Insulated Panels

Structured Wiring Systems

Substitute Aggregate Leach Field

Tankless Water Heaters

Termite Baiting

Tilt-up Roofs for Manufactured and Modular Homes

Trim-able Open Web Floor Truss

Tubular Skylights

Two-Part Universal Sealant Cartridge

Two-Stage Evaporative Cooler

Two-Story Manufactured (HUD-Code) Homes

Universal Design Bathtubs and Showers

Universal Design Kitchen Cabinet

Vacuum Insulation Panel (VIP)

Ventilation Control Systems

Vertical Axis (Top-Loading) Energy-Saving Clothes Washers

Water Cooled Evaporative Air Conditioning

Water Heaters With Space Heating Capability

White LED Lighting

Wide Span Metal Roofing

Window Film

Wireless Thermostats

Wood Foundations

Wood Interior Wall Paneling System

Wood Preservative - Low Toxicity

Xeriscaping 

